S T A T E OF I L L I N O I S

Dwight H. Green, Governor

DEPARTMENT OF REGISTRATION AND EDUCATION

Frank G. Thompson, Director

NATURAL HISTORY SURVEY DIVISION

Theodore H. Frison, Chief

\title{
The Prairie Chicken in Illinois
}

RALPH E. YEATTER

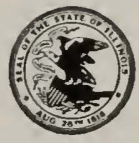

Printed by Authority of the State of Illinois

URBANA, ILLINOIS

May $19+3$ 
STA TE OF ILLINOIS

Dwight H. GREeN, Goqernor

DEPARTMENT OF REGISTRATION AND EDUCATION

FraNk G. THompson, Director

BOARI) OF NATURAL RESOURCES AND CONSERVATION

FRANK G. THOMPSON, Chairman

Will.am Trel.ease, D.Sc., LL.D., Biology

EzR। J. Kraus, Ph.D., D.Sc., Forestry

L. R. Howsox, B.S.C.E., C.E., Engineering

ROger AD.IMs, Ph.I)., I.Sc., Chemistry
ArThur Cutts WILl.ARd, D.Eng., LL.D.,

President of the University of Illinois

Edsox S. Bistix, Ph.D., Geology

\title{
NATURAL HISTORY SURVEY DIVISION
} Urbana, Illinois

\author{
Scientific and Technical StafF \\ Theodore H. Frison, Ph.D., Chief
}

Section of Economic Entomology

W. P. Fi.1NT, B.S., Chief Entomologist

C. C. Compton, Ph.D., Associate Entomologist

M. D. Farrar, Ph.D., Research Entomologist

J. H. Bigger, M.S., Associate Entomologist

S. C. CHANdier, B.S., Southern Field Entomologist

JAMES W'. APPLE, M.S., Northern Field Entomologist

B. G. BERGER, M.A., Assistant Entomologist

H. B. Pettr, JR., B.A., Assistant in Entomology Extension

C. J. Weinмix, Ph.I)., Special Research Assistant in Entomology

WILLIA.M H. HAsse, Entomological Assistant

JoHx M. WRIGHT, B.A., Junior Entomologist (U.S.B.E.P.Q. and Commodity Credit Corporation, cooperating)

Section of Insect Survey

H. H. Ross, Ph.I)., Systematic Entomologist

Carl O. Mohr, Ph.I)., Associate Entomologist, Artist (on leave)

B. D. Burks, Ph.D., Assistant Entomologist (on leave)

Mutuon W. Sandersos, Ph.D., Assistant Entomologist

KATHRYN M. Sommermax, M.S., Artist, Entomological Assistant

Section of Forestry

James E. DAvis, M.F., Extension Forester

I.EE E. Ye.IGER, Ph.D., Forester
Section of Aquatic Biology

David H. Thompson, Ph.D., Zoologist

George IV. Ben.ete, Ph.D., Limnologist

D. F. Haisen, Ph.D., Assistant Zoologist

Section of Game Research and Management

R. E. Yeatter, Ph.D., Game Specialist

Section of Wildlife Experimental Areas

Arthur S. Hawkins, M.S., Game Technician (on leave)

F. C. Bellrose, Jr., B.S., Assistant Game Technician

J. B. Low, Ph.D., Assistant Game Technician

W. H. Elder, Ph.D., Assistant Game Technician

Cooperative Wildlife Restoration Program

(State Department of Conservation and $U$. S. Fish and Wildlife Service)

Otto W. Tiemeier, M.A., Junior Biologist

Section of Applied Botany and Plant Pathology

L. R. Tenon, Ph.D., Botanist

D. B. Creager, Ph.D., Research Pathologist

J. C. Carter, Ph.D., Assistant Botanist

G. H. BOEWE, M.S., Field Botanist

Section of Publications

James S. Ayars, B.S., Technical Editor

Consultant: Herpetology, Howird K. Gioyd, Ph.D., Director of the Museum, Chicago Academy of Sciences These papers are contributions from the Section of Game Research and Management and the Section of
Wildtife Experimental Areas.

$(40936-3 \mathrm{M}-3-43)$

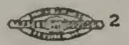




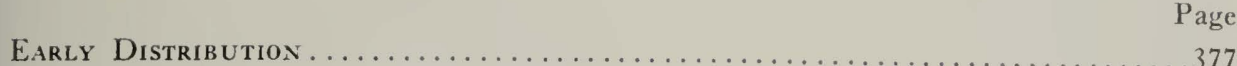

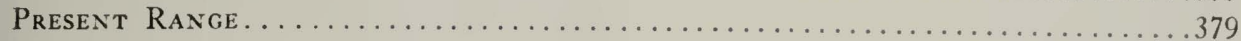

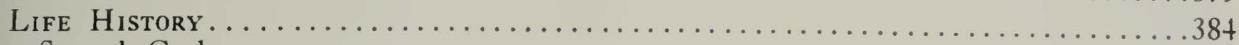

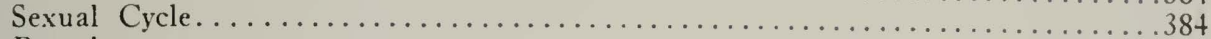

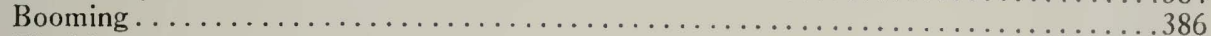

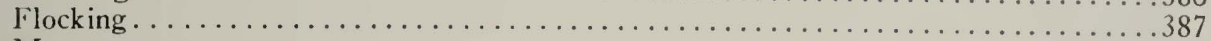

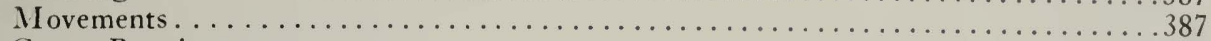

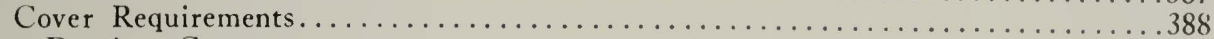

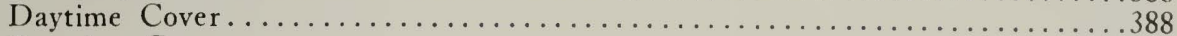

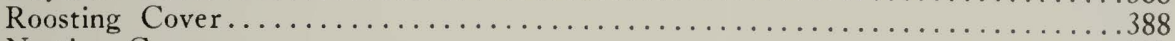

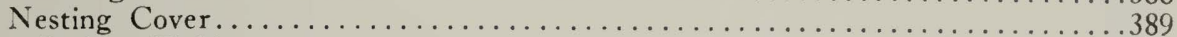

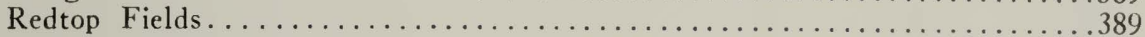

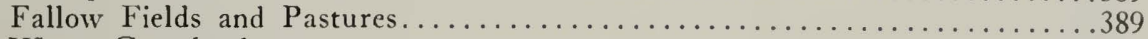

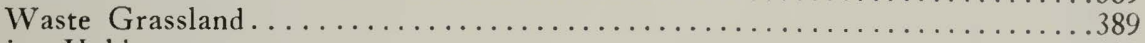

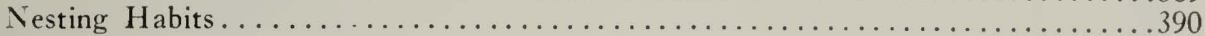

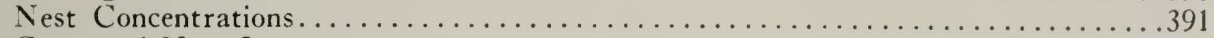

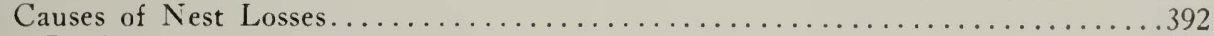

Predators . . . . . . . . . . . . . . . . . . . . . . . . . . . . . 392

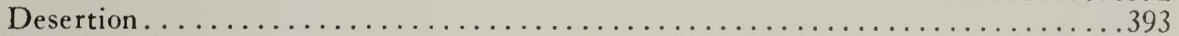

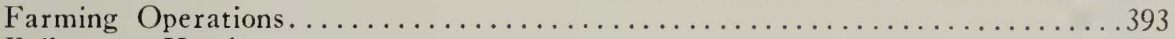

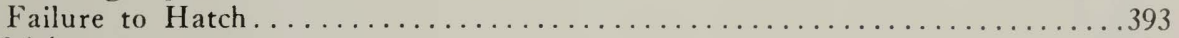

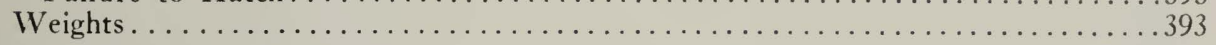

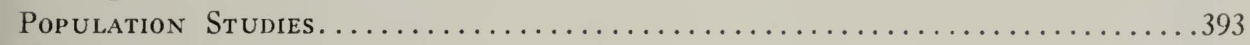

Mortality Causes. . . . . . . . . . . . . . . . . . . . . . . . . . . . . . . . . . 396

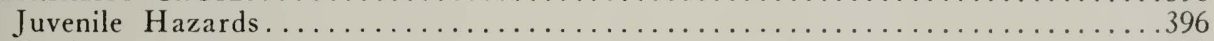

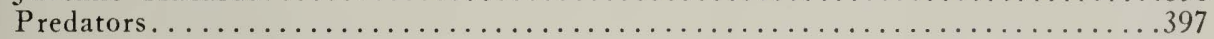

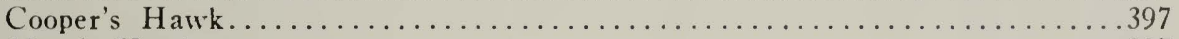

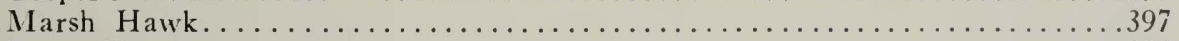

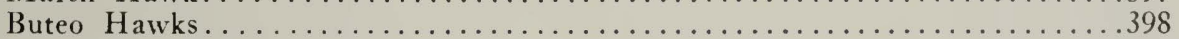

Great Horned Owil . . . . . . . . . . . . . . . . . . . . . . . . . . . 398

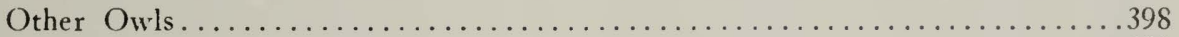

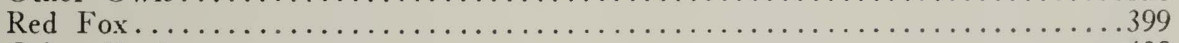

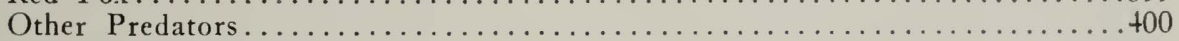

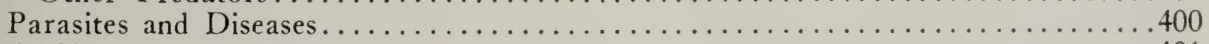

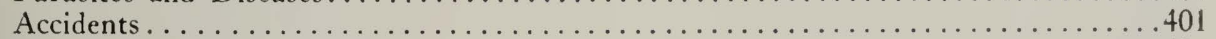

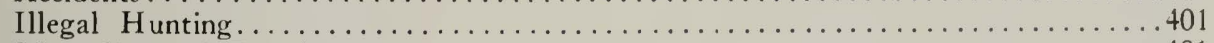

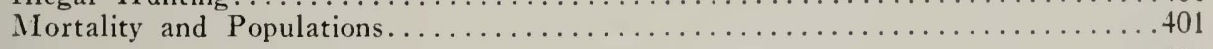

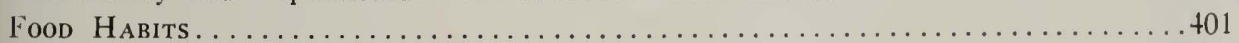

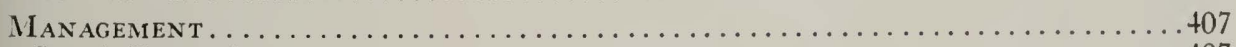

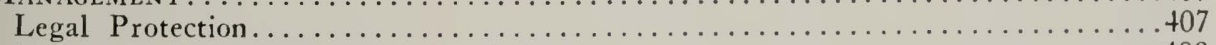

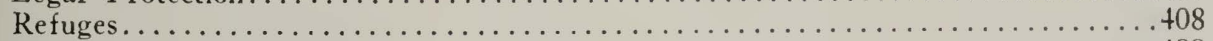

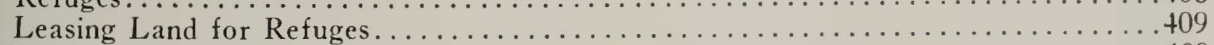

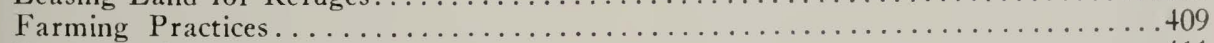

Predator Control..............................................

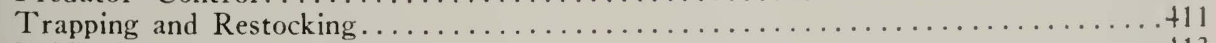

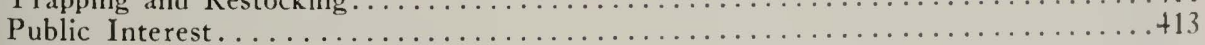

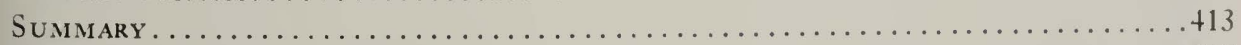

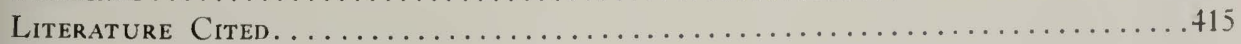




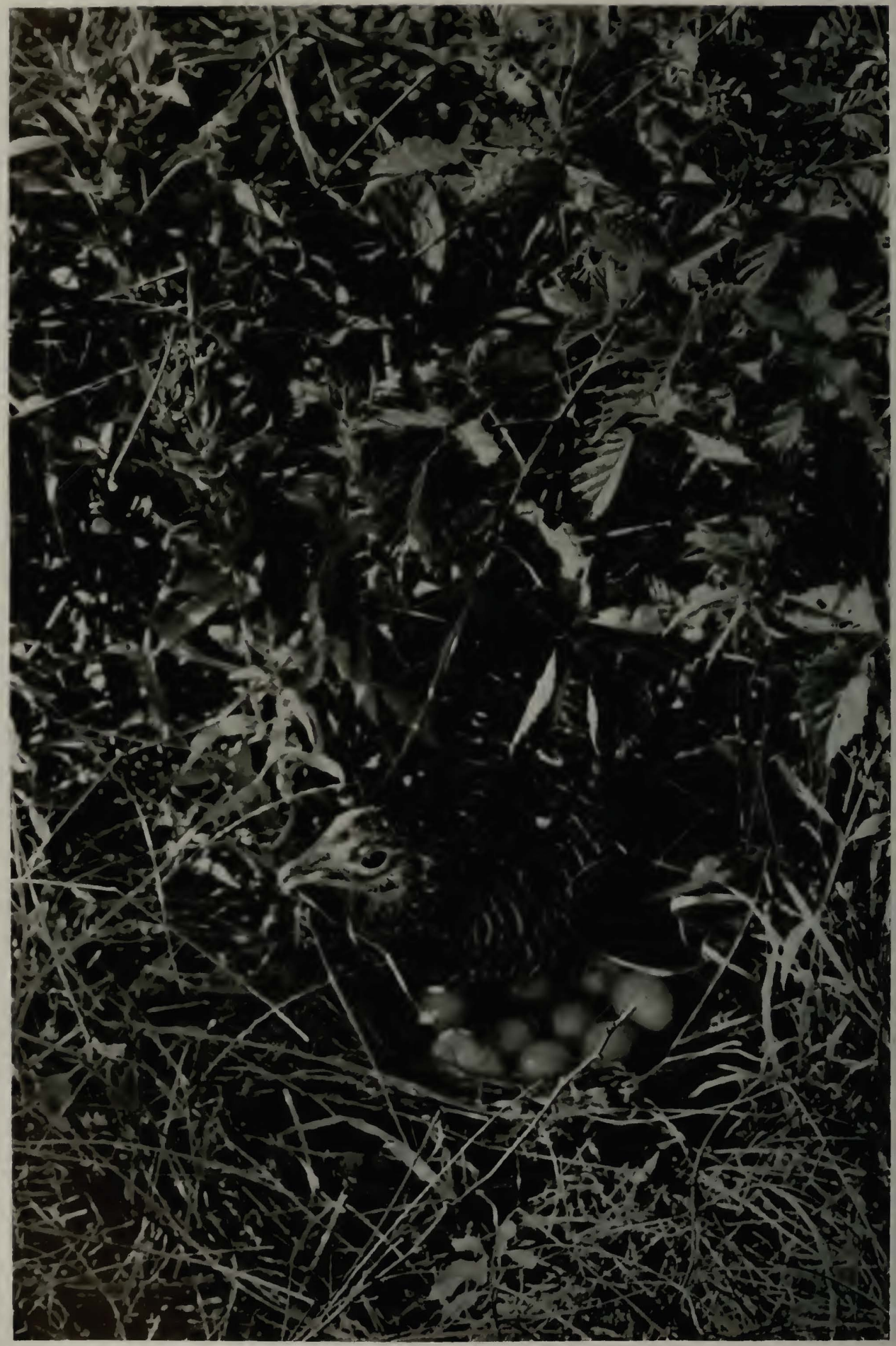

Female prairie chicken entering her nest, situated in a clump of grasses and dewberries. 


\title{
The Prairie Chicken
}

\section{in Illinois}

\author{
RALPH F. YEAT'TER
}

T HE greater prairie chicken, $T_{y} m$ panuchus cupido american us (Reichenbach), was formerly widely distributed over the grasslands of central North America. Because of its striking appearance, its characteristic breeding behavior, and its sporting qualities, it was well known to early generations of American naturalists and sportsmen. In spite of virtual extermination over much of its original range during the past threequarters of a century, this bird has persisted in fair numbers in a few favored prairie areas, and it has also extended its range hundreds of miles northward into cutover woodlands and farming sections in a number of northern states and Canada.

The occurrence of widely distributed local areas in which prairie chickens are maintaining themselves with some success has made possible a number of investigations by game ecologists, chiefly in the Mississippi valley, to discover basic requirements of this game bird and to outline measures to conserve and increase its numbers. Most of these investigations are still in progress.

The present report summarizes a study of the biology and management of the greater prairie chicken in Illinois, a study begun in 1935 by members of the Section of Game Research and Management of the Illinois Natural History Survey. The summers of 1935 and 1936 were spent in full-time field work in southeastern Illinois. Since that time, supplemental studies of prairie chicken habits, requirements and distribution have been continued in various parts of the state. Annually since 1935 , spring and fall censuses have been made on $t$ square miles of prairie chicken range in Jasper County used as a study area. Preliminary parasite and disease studies conducted by Leigh $(19+0)$ were published in another volume of the Survey Bulletin. 'The present report includes data on early distribution, present range, life history, populations, mortality causes, food hahits and management of the prairie chicken in Illinois.

The writer of this report is indehted to Dr. IV. Henry Leigh, formerly Assistant Zoologist of the Hllinois Natural History Survey, and to Mr. R. E. Hesselschwerdt, formerly Junior Biologist of the Survey employed on Federal Aid in Wildlife Restoration Act projects carried on in cooperation with the Illinois State Department of Conservation and the U.S. Fish and Wildlife Service; both gave invaluable assistance in the field studies in southeastern Illinois. Mr. Harry G. Anderson, formerly Junior Biologist of the Survey, like Mr. Hesselschwerdt employed on Federal Aid projects, kindly analyzed the food material found in prairie chicken stomachs. The cooperation of other members of the Survey staff, especially Dr. David H. Thompson, Mr. Arthur S. Hawkins, Dr. Carl O. Mohr, Dr. Herbert H. Ross, Dr. Leo R. 'Tehon and Dr. Lee E. Yeager, in various phases of this study is also acknowledged. The Illinois State Department of Conservation, through many of its game wardens, assisted materially in preparing the map, fig. 1, showing the distribution of prairie chickens in the state. The writer wishes to thank the farmers in the vicinity of Hunt, 1ll., who have allowed him to use their farms for field studies and census work.

\section{EARLY DISTRIBUTION}

Nearly 60 per cent of the state of Illinois was originally grassland. However, the first agricultural settlers arriving early in the nineteenth century aroided the 
grassland areas and settled in the timberlands along the rivers and streams. Treeless areas were then believed to be unsuited to agriculture and, although it was necessary to clear the land along the water courses, the soil there was better drained than was that of the prairies. Moreover, along the forest margins, game was abundant, and timber and fuel supplies were close at hand. In time, the high productivity of the grassland soil became apparent, and agriculture moved to the prairie.

As the Illinois timberlands were cleared and put under the plow, prairie chickens extended their range into these areas from the adjacent prairies, in which the first settlers had found them. Later, as the prairie sod was broken and grain became common, chicken populations increased enormously throughout the grasslands. The highest populations, resulting from the early development of agriculture, seem to have occurred during the 1860 's.

Favorable conditions created by interspersion of crop land and unbroken prairie were reversed, however, as Illinois agriculture developed from the primitive stage, much of it into highly intensive grain farming. The prairie chicken then began to decline over large areas of its range.

Leopold (1931) says of this period: "The prairies of Illinois, however, which Hatch describes as poor in 1836, and where Bogardus describes chickens as only 'rather numerous' in 1857, had in $187+$ just passed their prime as chicken country."

The period of 1850 to 1880 was one of rapid agricultural development in Illinois. By 1880, the acreages of all farm land and of improved land in farms were reported greater than at present. Much of the improved farm land, however, did not hecome fully productive until later, when it was artificially drained (Case $\mathbb{S}$ Myers 193t). Merritt (190t) states that game declined markedly in northwestern Illinois during the upturn of agriculture immediately following the Civil War. Probably a similar trend held true for much of the state. Undoubtedly heavy hunting pressure then and later hastened the decline of prairie chickens, but a widespread decrease was inevitable under the practice of intensive grain farming and grazing that was developing in the dark soil prairie counties. The heyday of the nonresident sportsman and market hunter seems to have ended during this period.

Over half a century ago, we find the American Field (Aug. 27, 1881) advising its readers that prairie chicken shooting was no longer good in Illinois or Missouri. Central Illinois was said to have few birds. For good shooting, it was necessary to go "west of the center of lowa and Minnesota."

In spite of the decline of prairie chickens, there were still, in the early ' 80 's, occasional records in the hunting journals of fairly large kills in the east central counties of the state. However, on June 9, 1887, the Illinois State Legislature passed game laws that included a provision for a closed season on prairie chickens and ruffed grouse during 1887 and 1888 , indicating increasing concern over the welfare of these birds.

At the beginning of the present century, prairie chickens were still rather generally distributed on the Illinois prairie, but were to be found only locally and in greatly reduced numbers in the dark soil counties. Under intensive agriculture and drainage, the remaining habitats were being broken into smaller and smaller units, leaving colonies in only the most favorable localities. In 1903, the season on prairie chickens, then of 30 days, was closed abruptly, and hunting was not again legalized until 1911. Following this action, shortened seasons of 5 to 15 days, with a daily bag limit of three birds, were tried until 1933. Nevertheless, chicken populations continued to decline. In 1933 the season on prairie chickens was closed and has not since been reopened.

About 30 years ago, Forbes (1912) reported, on the basis of information received from game wardens, that prairie chickens were present in at least $7+111$ inois counties (nearly twice as many as in 1942). Reports received by Forbes in 1912, and now in the Illinois Natural History Survey files, indicate that prairie chickens were then holding their own or increasing in some of the less adequately drained areas in eastern Illinois, but becoming rare in the central part of the state.

Leopold's (1931) game survey of the north central states disclosed no colonies in the dark soil upland prairie counties 
west of the Illinois River, although several local colonies were still present in the east central, the northern and the southeastern counties. In these southeastern counties is the main Illinois range of the prairie chicken today.

The period 1930 to 1935 saw the disappearance of nearly all of the remaining colonies in the east central counties, and a reduction of birds in the northeastern marshlands. One of the last prairie chicken flocks remaining in the central part of the state was on the South Farm of the University of Illinois at Urbana, where birds were reported present until 1932 by Dr. W. L. Burlison, Head of the Department of Agronomy of the College of Agriculture.

\section{PRESENT RANGE}

A survey of the range of the prairie chicken* in Illinois in 19+0, fig. 1, shows two general regions of importance: about 50 square miles of sand prairie along the Green River in Lee County, northwestern Illinois, and approximately 2,600 square miles in the gray soil prairie in the southeastern counties.

To these regions may be added about 200 square miles of small occupied areas, principally in northern and south central Illinois. The total occupied territory, approximately 2,850 square miles, represents about 9 per cent of the area of grassland soils in the state, most of which were undoubtedly occupied by prairie chickens in the presettlement era.

It is evident that prairie chickens have persisted best in areas of the poorer prairie soils where fallow land or special farming practices provide more favorable environment than that in the intensively farmed areas. These birds survived longer on the heavy, dark soil of east central Illinois than on the upland prairie west of the Illinois River, probably because the east central area was poorly drained, hence less intensively farmed, until a comparatively recent date and was also less intensively grazed by livestock. Apparently the birds disappeared first from the acquired woodland range and then from the adjacent prairies, their original habitat.

*Throughout this paper the term prairie chicken, as it relates to Illinois birds, refers to only the greater prairie chichen, Tympanuchus cupido americanus (Reichenbach).
It is notable that a considerable number of small, scattered colonies, in some cases now only a few dozen birds, are to be found in the dark soil counties of northern and north central Illinois, where they have persisted for many years around marshlands or other accidentally preserved habitats. However, many such isolated colonies reported by Leopold (1931) have disappeared during the past dozen years. Without intelligent management, it is extremely likely that all of the remaining colonies in northern Illinois will eventually be lost. In southeastern Illinois, the prospects for the survival of prairie chickens are better, although the outcome there depends chiefly on future agricultural developments and the conservation policies pursued with respect to these birds.

Nine major types of farming areas in Illinois are defined by Case \& Myers (1934), fig. 2, who state, "By 'type-offarming area' is meant an area in which one or more dominant types of farming can, in most cases, he easily distinguished and within which natural agricultural resources and biological and economic conditions are highly uniform."

Reference to the distribution map, fig. 1 , and the map showing the major types of farming areas in Illinois, fig. 2, will show that the chief Illinois prairie chicken range lies almost entirely in the southcastern mixed farming section, Area 7, with the largest part of it lying in the central portion, Area $7 \mathrm{~b}$, which is the most important center of redtop seed production in the United States. 'The range extends well into Areas $7 a$ and $7 c$, although redtop, Agrostis alba Linnaeus, is grown somewhat less extensively and the ratio of prairie soil to woodland type soil is smaller there than in $7 b$. Fig. 3 shows typical prairie chicken range in Area $7 b$.

Area 7 is in the so-called "gray prairie" soil region of southeastern Illinois, characterized by light-colored silt loams and poorly drained, tight clay subsoils. These soils are of relatively low productivity and are strongly acid. Because of acidity as well as poor drainage, they are not suited to growing leguminous hay crops unless heavily limed. Case \& Myers (193t) state, "The low yield of grain crops on untreated land in Area 7 and the cost of liming has led to the replacement of grain crops with redtop, which 


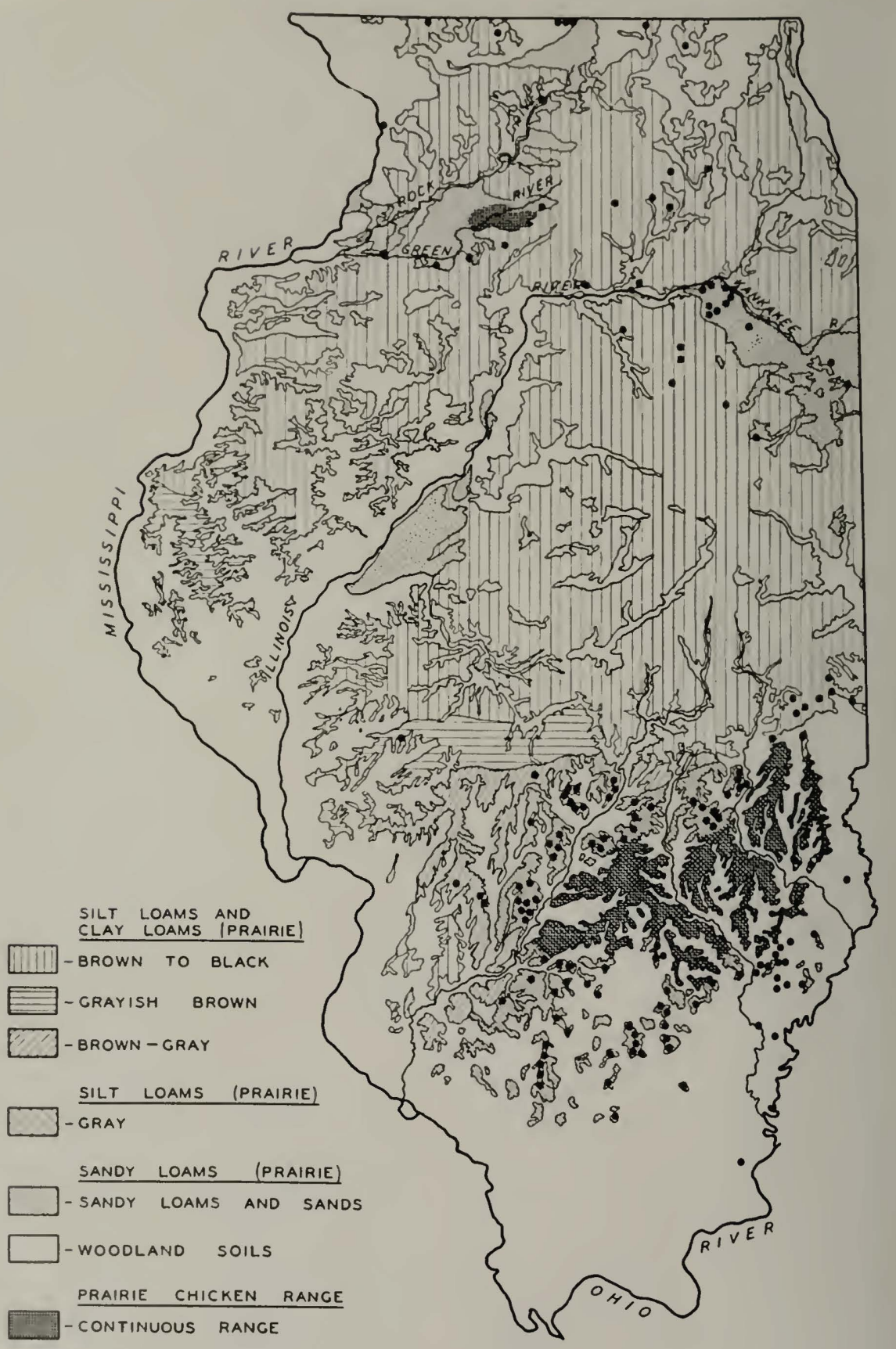

- isolated colony

Fig. 1.-Distribution of prairie chickens in Illinois, 19+0; showing relation of the range to certain prairie soils. The continuous prairie chicken range in southeastern Illinois coincides with much of the gray prairie silt loam in that part of the state. The continuous range in the northern part of the state is in an area of sand prairie. Only those isolated colonies the location of which could be verified by the writer are indicated on the map. Map adapted from University of Illinois Agricultural Experiment Station soil survey map of 1935 and vegetation map by Vestal (1931). 
can be grown at little cost, and with special crops such as fruit."

Grown in southern Illinois since about 1875 , redtop may be either a seed or hay crop. The seed is one of the chief cash crops of the region.

Burlison, Stewart, Ross \& Whalin (1934), who state that approximately 85 per cent of the world's redtop seed and 95 per cent of the redtop seed pro- duced in the United States are grown in south central Illinois, point out that the concentration of redtop production in that region has been due to a combination of economic factors, favorable climate, and soils not well adapted to other crops.

The cropping system practiced in Area $7 b$ is illustrated by the following approximate percentages of acreage in various crops and idle land in 1929: corn 18 per

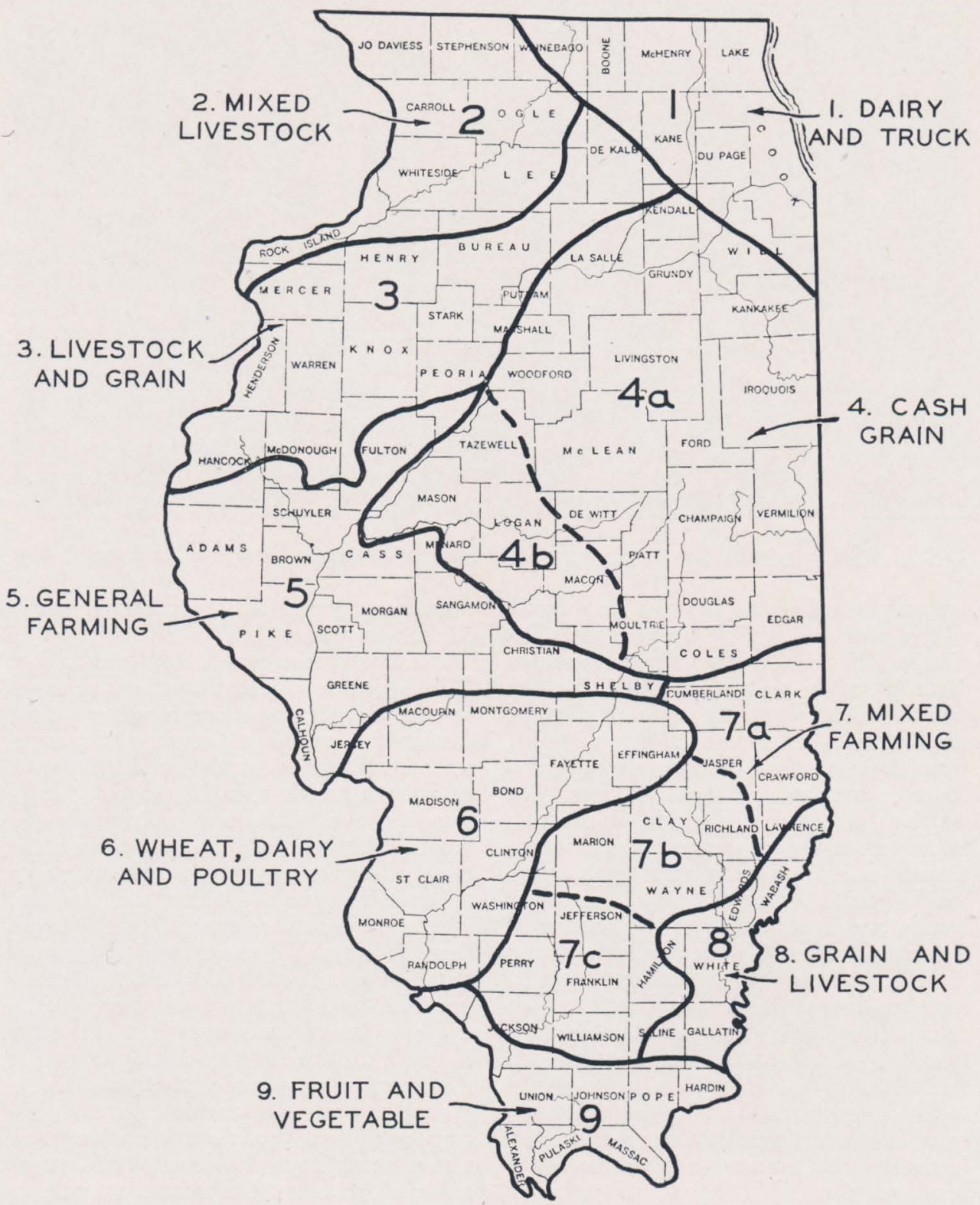

Fig. 2.-Nine major types of farming areas in Illinois. After Case \& Myers (1934). 
cent, small grains 5 per cent, hay (chiefly redtop) $2 t$ per cent, other crops 8 per cent, pasture 28 per cent and idle land 17 per cent (see the graph on page 160, Case \& Myers 193t). In recent years, the amount of idle land has declined to about 7 per cent, and soybeans have come into use, chiefly as a hay crop.

Probably no other locality in the state is toward cleaning up fencerows and thickets. As a result, quail populations have been reduced somewhat in the past few years. 'The recent increase in the amount of soybeans grown in this region and low prices for redtop seed have made inroads on the acreage of redtop and idle land. However, this development does not at the present time appear to have

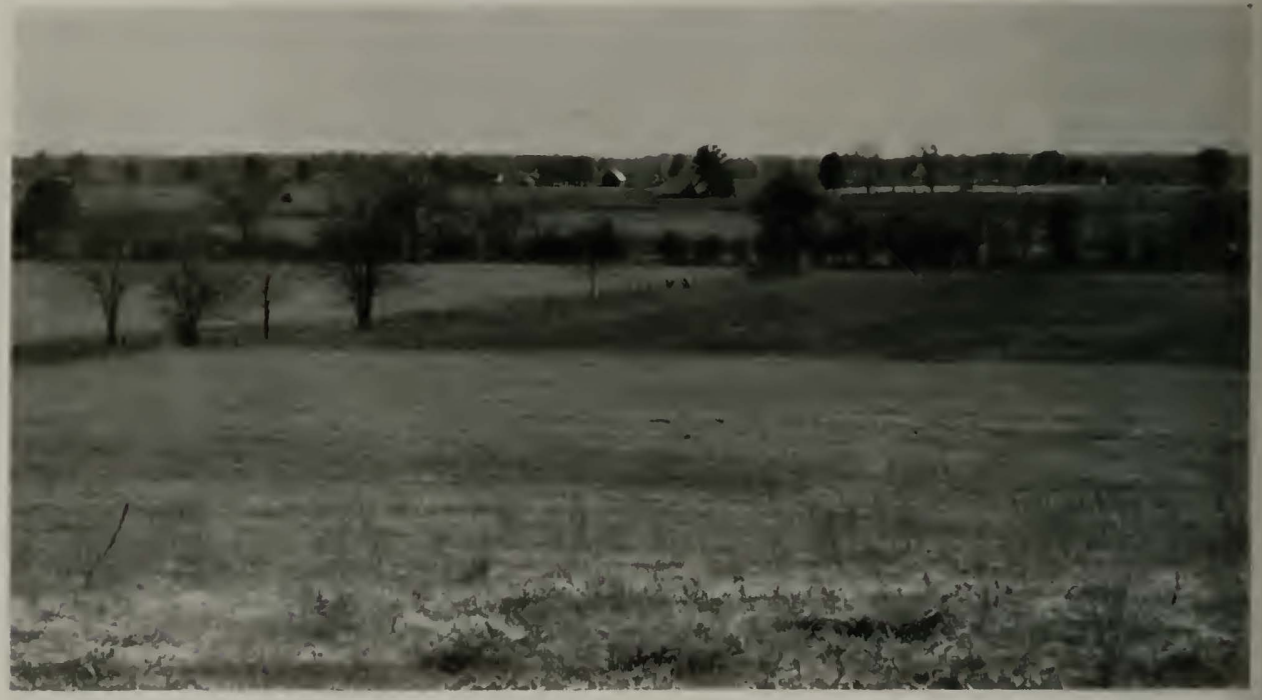

Fig. 3.- The type of farm land occupied by prairie chickens in southeastern Illinois.

has maintained its native wildlife as well as the gray soil prairie region of southeastern Illinois. Birds nesting in numbers there in redtop and fallow fields include prairie chickens, quails, upland plovers, marsh hawks, meadowlarks, horned larks, Henslow's sparrows, field sparrows, grasshopper sparrows and several others. On the flat uplands of this region, in addition to numerous osage orange hedges, young pin oak, shingle oak, blackberry, raspberry; hazel, panicle dogwood and other cover species are common in many fencerows and waste areas. This cover, figs, $t$ and 5 , in connection with cultivated grain crops, redtop and fallow fields, makes this area so favorable for quails and rabbits that it attracts hundreds of bunters each fall.

Wildlife populations, especially of the brush-inhabiting species, are of course affected by the amount of idle land and brush present. 'This varies with economic conditions. The trend under present relatively high prices for agricultural products caused an appreciable reduction of prairie chicken numbers.

Although there can be little doubt that Illinois prairie chickens inhabited cleared woodland soils to a considerable extent during the period of crude agriculture, these birds are at present confined almost entirely to prairie soils. Bennitt's (1939) map of the distribution of prairie soils and prairie chickens in Missouri shows the close relationship of the remaining range to certain types of prairie soils in that state. In southeastern Illinois, where there is extensive interspersion of woodland soil areas with the prairie or grassland soil areas that harbor prairie chickens, as a rule the only woodland soil farms on which chickens are found are those that immediately border the prairic.

One explanation for the apparent preference of lllinois prairie chickens for prairie soils may lie in the density and composition of grass and herbaceous growth, as well as in the type of plant succession, found on the prairie. Visual appraisal of 


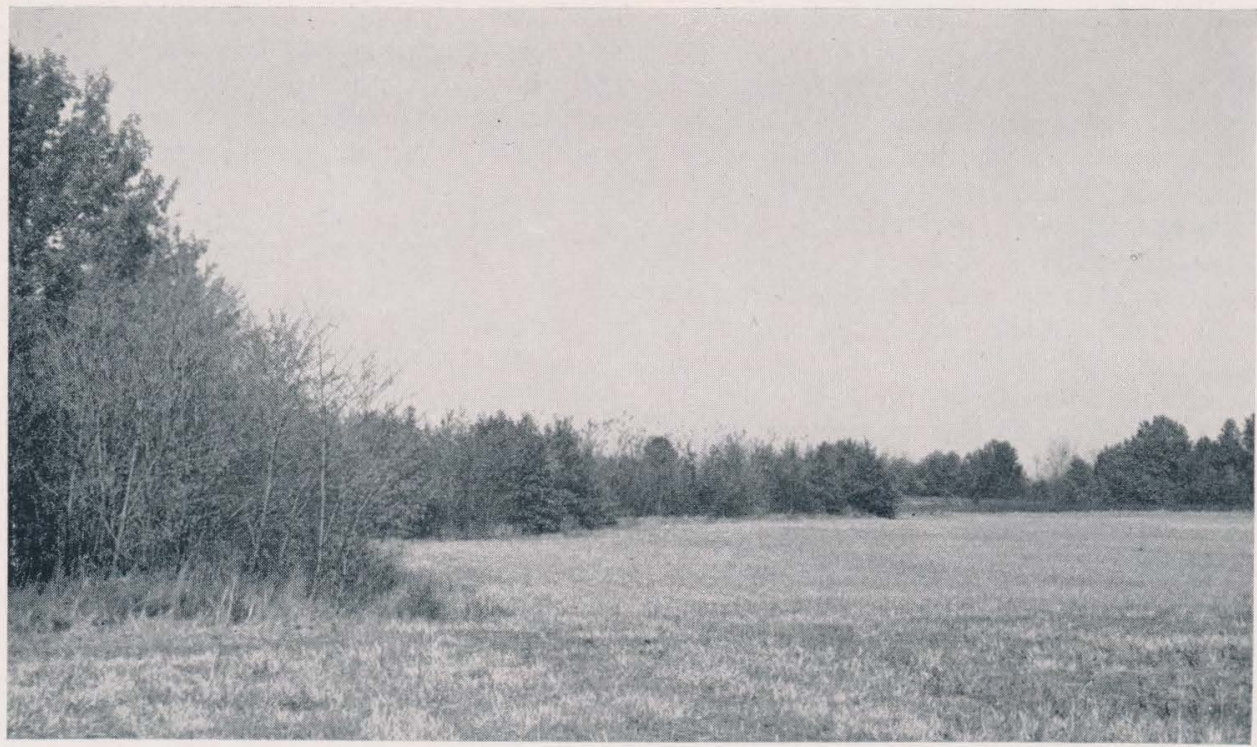

Fig. 4.-Cover used by small game in southeastern Illinois; a growth of young pin oaks, shrubs and berry vines along a stream.

typical areas of vegetation on prairie and on woodland type soils gives the distinct impression that the cover requirements of the prairie chicken are met more adequately at present by the prairie growth than by vegetation found on woodland type soils. Redtop, for example, on the prairie usually makes somewhat better ground cover than on woodland type soils; the older redtop fields on the prairie develop typical patches of dewberries and herbaceous plants that provide favorable nesting places, especially along the margins, while redtop stands on woodland type soils sel-

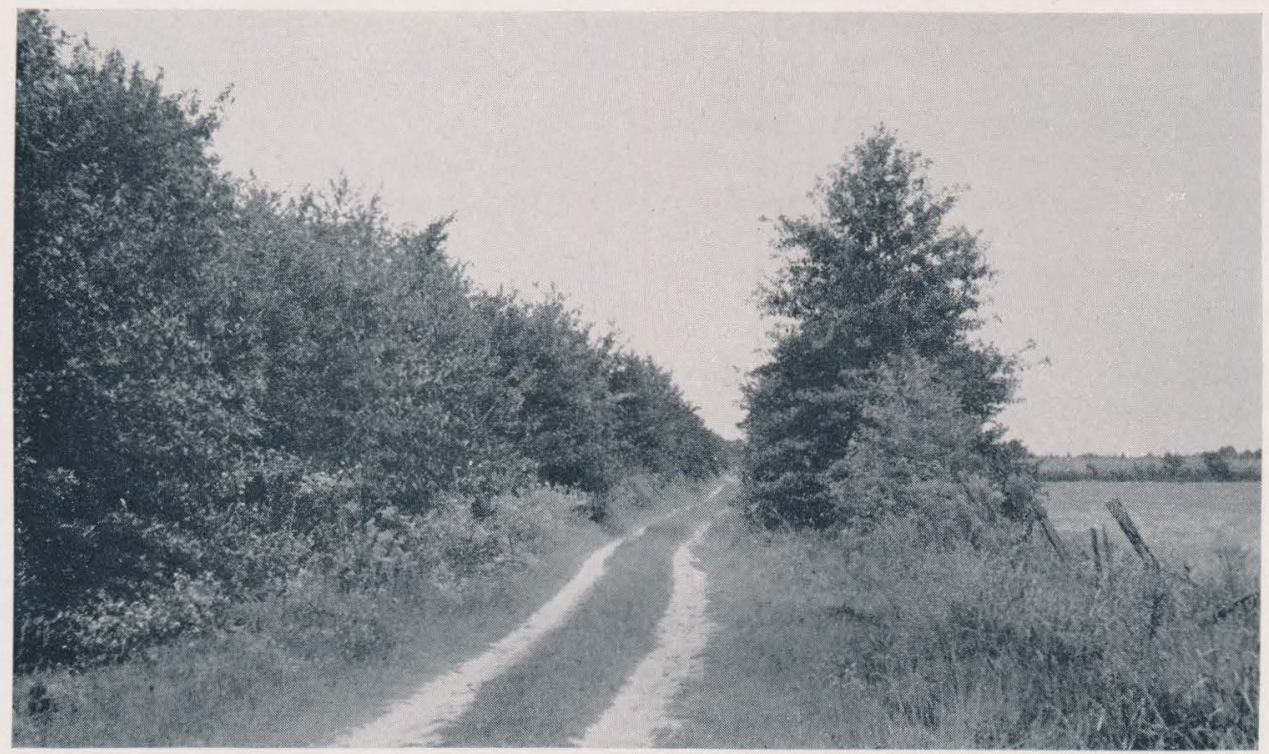

Fig. 5.-Cover used by small game in southeastern Illinois. The dense growth on the left is an osage orange hedge. The larger tree on the right is a shingle oak. 
dom furnish such favorable combinations of regetation.

The importance of uncultivated areas, especially grassy areas, in prairie chicken management is stressed by Gross (1930), Leopold (1931), Bennitt \& Nagel (1937), Hamerstrom (19+1). Grange (19+1), Lehmann (19+1) and others.

Because soils comprising the present major range of the prairie chicken in Illinois are of relatively low agricultural value, the percentage of land that lies idle annually is higher there than in the hetter portions of the prairie. 'This uncultivated land, which furnishes a certain amount of cover and food, must he regarded as a contributing, but secondary, factor in the successful stand of prairie chickens in southeastern lllinois, since these birds are maintaining themselves in fair numbers in certain redtop-producing localities where there is practically no idle land.

During the present study it became increasingly apparent that the redtop crop grown in a dozen counties in southeastern Illinois was admirably adapted to meet the cover and space requirements of prairie chickens at various times of the year, including the period of the elaborate courtship performance. Of paramount importance is the fact that harvesting of the redtop crop is not hegun until approximately July 1 or July 15 , depending on whether the redtop is grown for hay or seed. Because of the lateness of the harvest, redtop provides a habitat somewhat like the native prairie during the critical nesting period and while the birds are very young.

Contrary to the common belief that prairie chickens will thrive only where tracts of wild lands remain, in southeastern Illinois these birds are found in fields close to farm buildings, where they are in frequent contact with domestic turkeys and chickens, thus providing notewortly evidence of a potential adaptability to settled communities.

Although, in some instances, prairie chickens have persisted for long periods in dark soil prairie districts, where up to 85 per cent of all farm land is plowed annually, their rate of reproduction in most districts of this type has been too low to prevent their ultimate disappearance. 'The farming practices now widely. employed in dark soil prairie regions do not provide the habitats essential to prairic chickens, and, unless conditions change markedly, the less fertile prairie soils will continue to be the chief range of these birds in Illinois.

\section{LIFE HISTORY}

'The life history of the prairie chicken has heen studied in detail by several workers whose observations are acknowledged below. Many of the findings of these workers have been verified by field work, principally on the Jasper County study area in southeastern IIlinois, which has yielded new as well as supplementary information.

\section{Sexual Cycle}

In southeastern Illinois, male prairie chickens, while still in winter flocks, may show the first evidence of the mating display during mild weather as early as late

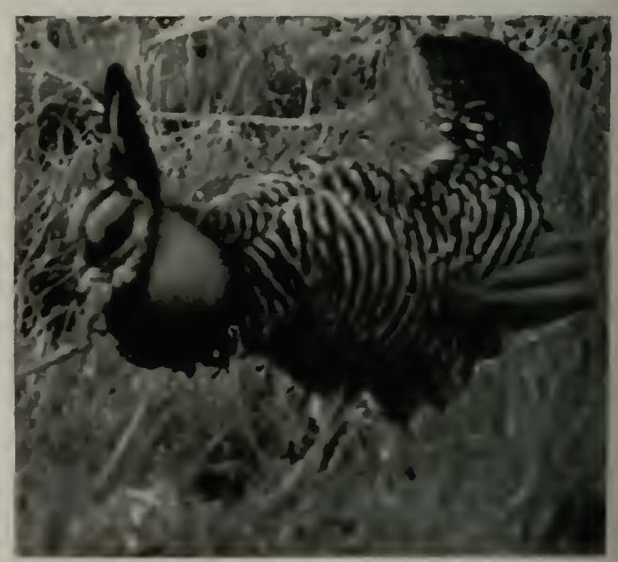

Fig. 6.-Male prairie chicken at the climax of the booming performance.

January or the first few day's of February. At first this activity consists of fighting, strutting and loud cackling, but a few days later the first characteristic booming, fig. 6 , may be heard from the booming grounds. 'The earliest date booming has heen heard by the writer is January 30 , in 1939.

For several weeks after the first males appear on the booming grounds, flocks of chickens, consisting apparently of both females and those males that have not yet 
begun to display, are commonly seen staying close to the booming grounds. On March 1, 1939, apparently less than 10 per cent of the total prairie chicken population of the Jasper County study area were males in which the booming and displaying performance was fully developed.

In an intensive study of the breeding habits of prairie chickens in IVisconsin,

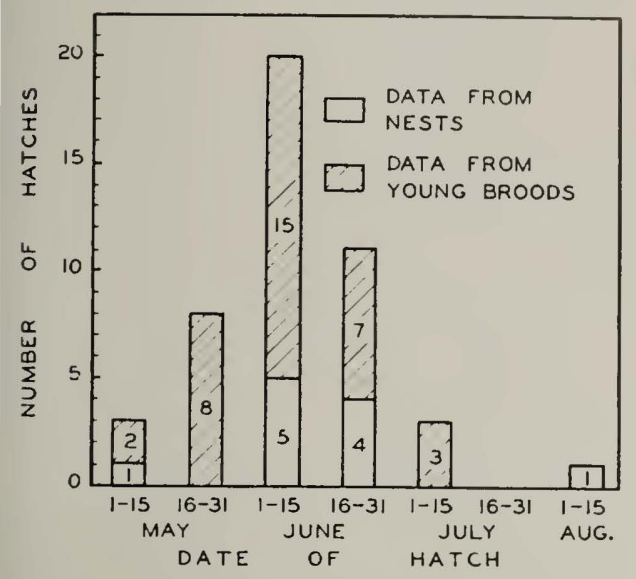

Fig. 7.-Hatching period of prairie chickens on the Jasper County study area, chiefly in 1935 and 1936. Some of the hatching dates were obtained from nest observations and others were calculated from careful estimates of the ages of young broods encountered in the field.

Hamerstrom (19+1) brought out many behavior details that apply substantially to southern Illinois chickens.

Hamerstrom found evidence that the males, and probably the females, do not all arrive at the breeding stage at the same time, but rather show a spread of several weeks in the stage of development of the sexual cycle, a characteristic noted by other investigators in one or both sexes of certain other gallinaceous birds. Studies of the behavior of prairie chickens in southern Illinois indicate that such a time lag in the development of the sexual cycle exists among birds of both sexes.

In male birds the development of the sexual cycle during early spring is accompanied by a gradual increase of the yellow pigmentation of the neck and eye regions, as well as by an increase of booming and fighting. Considerable difference in the development of these manifestations has been commonly noted among males on and near the booming grounds. In the latter part of the breeding season, this differential development of the cycle is indicated by the gradual disappearance from the booming grounds of males that apparently are becoming sexually inactive. In southeastern Illinois, the period of greatest booming activity appears to he about the last week of April. By May 10 a lessening of display is usually evident. By early June only a small fraction of the peak number of males is still present on the booming grounds. By the second week of June the booming period is practically over.

The hatching period for the prairie chicken in southeastern lllinois is indicated by the accompanying graph, fig. 7 . This graph, which shows the distribution of prairie chicken hatching records obtained in Jasper County, chiefly in 1935 and 1936, is hased partly on nests under observation and partly on coveys of young birds encountered in the field. Hatching dates of the coveys were calculated from careful estimates of the ages of the young birds.

It will be seen that, in the years included in the graph, hatching began during the first half of May, reached a peak during the first half of June and tapered off during the first half of July. Although the later hatches probably in part represent renestings after failure of earlier attempts, the total evidence from observations on females at the booming grounds and accumulated field records on the beginning of nests supports the belief that considerable variation exists among females as well as males relative to the time at which breeding takes place. On the whole, such an extended breeding $\mathrm{cy}^{-}$ cle appears to be a useful adaptation by the prairie chicken to its Huctuating and often unfavorable environment, where poor cover, activities of enemies or unfavorable weather might otherwise at times cause heavy losses of nests or very young birds.

Cold, stormy weather delays the start of the mating display among prairie chickens. Later it may cause a temporary halt of sexual activity and even a return of winter flocking habits. It is possible, also, that cold weather or other unfavorable weather conditions may delay the start of the breeding season. Although the tend- 
ency for southeistern Illinois prairie chickens to form large flocks is usually orer by the third week in March, it was noted in 1940, following a cold, rainy April, that many birds were showing a tendency to Hock as late as the first week in May. The breeding season, usually at its height at this time, was apparently held back ly unfarorable weather conditions.

\section{Booming}

Booming grounds in southeastern lllinois are usually on slightly elevated terrain, but in northern Illinois they sometimes occur on level bottoms of potholes or ne:tr the edges of ponds. On the pond sites, a rise of an inch or so of water may fail to drive the male birds from their established territories. The favorite place appears to be a pasture or meadow where the vegetation is short. Booming grounds have been observed also on winter wheat fields, idle fields, stubble and bare ground. When the grounds are plowed during the mating season, the birds may continue to hoom on the plowed soil.

The chief booming periods during the height of the season are for 3 or 4 hours after dawn, and from late afternoon to near dark. These periods are marked by continuous strutting, booming, cackling and fighting between pairs of male prairie chickens.

The booming is a resonant, three-syllabled call, described by Grange (1940) as "Zoovoo ... woovo ... youoo," the second syllable lower than the first and the third rising above the first. These calls given by several birds at once blend into a continuous tone of near trumpetlike quality that can often be heard for well over a mile. In early morning when three or more groups are heard booming simultaneously, the effect produced is like the droning of a huge hive of bees.

It has been generally assumed that, during the booming performance, the female birds in the vicinity are attracted and that mating takes place at the booming grounds, but, although occasional matings are observed there, the studies of Hamerstrom (19+1) and Main (1937) indicate that the bulk of mating activity may take place off the main booming grounds.

Although the same hooming ground may be used for several years, it is a com- mon occurrence in southeastern Illinois for chickens to shift after a year or two to a new site in an adjacent field, or for a group to appear in early spring at some distance from a previously used site. Only 1 of approximately 20 booming grounds under observation each spring in southeastern Illinois has been used continuously. for as long as 7 years. Undoubtedly; farming operations account for many of these shifts.

The average number of males per booming ground in and near the Jasper County study area apparently has varied only slightly from year to year. However, the number of booming grounds in use has shown considerable variation from year to year, corresponding to population changes. For example, in late April, 1939, when there were 12 booming grounds on the study area having $t$ or more males, the average number of males per booming ground was 9.9. In 19t0, on 7 booming grounds having $t$ or more males, the average number of males was 8.9 , and in $19+2$, when there were only 6 booming grounds, the average number of males was 9.3. It was noted in southeastern Illinois that during the summer months, after the booming season, certain groups of adult males tended to stay together in the vicinity of the booming grounds; a similar tendency is recorded by Hamerstrom (1939) in Wisconsin.

The largest number of displaying males seen on any established booming ground in southeastern Illinois is $2 t$; however, the maximum number observed during any spring has seldom exceeded 17 or 18 . Not infrequently single hirds or pairs take stations at some distance from regular booming grounds and go through the courtship display daily for weeks.

It was observed in the spring of 1939 , following a marked increase in the prairie chicken population of southeastern Illinois, that new booming grounds were established in a poorly drained part of the study area which had been little used by the birds during any previous spring. Subsequently, when the population of the study area declined, some of the new booming sites continued in use, while certain older grounds were abandoned. It is possible that these new booming grounds were formed chiefly by young males, some of which returned to them during the 
following years. The presence of males on the new booming grounds apparently attracted females and led to the establishment of a local population on a previously unused portion of the study area. A similar sequence in the establishment of new colonies was observed by Franklin J. W. Schmidt (Leopold 1933) during his study of prairie chickens in IVisconsin.

\section{Flocking}

During the first few weeks after hatching, the prairie chicken young are kept closely concealed by the females. By the first week in June in southeastern Illinois, occasional early hatched broods, about 3 weeks old, can be observed. However, the best opportunity to observe the young comes after the redtop is harvested in mid July. A tendency for broods to combine loosely is evident in midsummer. It is not uncommon in late July and August to see two or more females together with young of different sizes. Such combination broods were observed with field glasses several times during field work in the summer of 1936, and on August 11, 1936, two young, one apparently about 5 weeks and the other 8 weeks old, were collected from the same flock.

Although single broods or small combined groups are in evidence throughout the summer, the flocking tendency becomes more evident toward fall. For example, on Aug. 17, 1937, 33 birds feeding in a southeastern Illinois bean field combined into a single flock when flushed. By October, although most of the chickens flushed are in flocks of less than 20 birds, the tendency to form large temporary flocks is evident; as many as 50 birds have been seen together by Oct. 15. In late autumn and winter, flocks ranging from a dozen to 75 birds are common. The largest winter pack seen by the writer in Illinois was approximately 110 birds, counted in flight in Jasper County, on Feb. 10, 19+2. Despite the flocking tendency, some small groups or single birds are always encountered during winter field work.

\section{Movements}

Leopold (1931) gives several records showing winter migrations of prairie chickens from northern districts to areas at least as far south is central lllinois. The latest date of migration of large numbers of chickens given by Leopold was 1908 ; it related to a large flight southward through western Peoria and eastern Knox counties. Since this flight occurred in early fall, it may have consisted of local rather than northern birds. Leopold quotes a statement made in $187+$ by $\mathrm{A}$. H. Bogardus that in Logan County, in the latter part of the fall, chickens were then nearly as numerous as in the late '50's, but young birds in August and September were said to be much less numerous than formerly. A former practice by market hunters of shooting prairie chickens during their southward flight along the Mississippi bottoms in Henderson County is mentioned by Leopold.

Reports received by the writer from old time residents of the east central part of Illinois indicate that up to 50 years ago, or later, flocks of migrating prairie chickens were still occasionally encountered in that part of the state in winter.

Recent censuses of the Jasper County study area show that local fall and early spring movements of prairie chickens occur regularly in that locality. The south slope of a low hill which covers about a third of this areal has for many years been a favorite wintering ground for prairie chickens, and each year an influx of at least a few dozen birds, apparently from nearby areas, to this spot lias been noted, fig. 8. The most noteworthy concentration occurred in the winter of 1938-39, when local populations were at the highest point reached during the period of investigation, 1935 to the present time.

A census of the t-square-mile study area concluded on Nov. 9, 1938, showed a total of approximately 255 prairie chickens. By the end of Iecember, birds appeared to be much more numerous than in November. A second census in late February and early March, 1939, showed that the population had risen to nearly t00 birds. By mid March it was evident that a considerable number of birds had left the area. A March dispersal of birds from their wintering grounds has been observed repeatedly during the study. 'This appears to have been chiefly a local movenent, affecting only the birds in the vicinity of the study area. However, since 
little banding has been done, the full extent of movement of birds in this region is unknown.

\section{Cover Requirements}

Although prairie chickens in southeastern Illinois inhabit a variety of crop or pasture lands, as well as suitable waste arean, they show a preference for redtop fields at most seasons; the growing redtop ter, prairie chickens spend much time in the open fields. 'They feed largely in cornfields, soybean fields and small grain stubble. During snowstorms they frequently seek low spouts in standing corn or shocked corntields. 'Thev have been ohserved during blizzards seeking protection at the bases of corn shocks.

The use made of fallow or idle fields for daytime cover depends chiefly on the stage of succession of the vegetation. Old

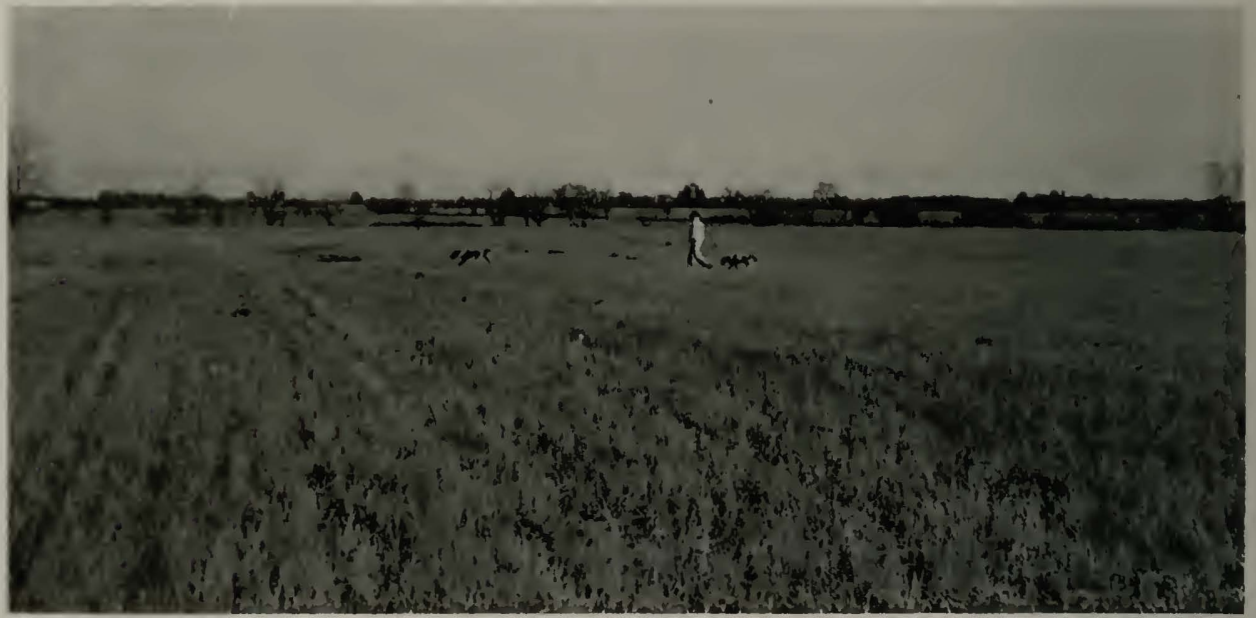

Fig. 8.- These fields on the south slope of a low hill in the Jasper County study area are a favorite gathering place for prairie chickens in late fall and winter. Redtop stubble seen in the foreground is much used for winter cover.

in early spring and its stubble in autumn and winter furnish favored resting places and fair concealment.

Daytime Cover.-When newly hatched, the young chickens are kept by the females chiefly in redtop fields, but to some extent in small grain or grassy fallow fields. In midsummer, young and old birds feed largely in small grain stubble, redtop stubble and soybean fields. During the heat of the day, they retire to the shade of trees or small shrubs along fences, osage orange hedges and cornfields. In cultivated fields, their dusting pits are frequently seen, often each with a spreading herbaceous plant or a corn hill serving as overhead cover for the young or adult bird while dusting. In late July and August, before the young are fully developed, they have commonly been observed to fly, when Hushed, to the edge of a nearby cornfield, which serves as a convenient escape cover area.

During autumn, and even in midwin- cornfields or stubble may be frequented by prairie chickens during the first year the fields are idle, but when aster, fleabane and goldenrod cover the ground these areas are little used except in winter and early spring when such plants have been Hattened. Later, when grass and brambles begin to crowd out the thick herbaceous growth, the fields may again be used as nesting and roosting areas.

Roosting Cover.--Schmidt (Leopold 1936) found that suitable roosting cover was a factor in determining the summer range of prairie chickens in IVisconsin. In southeastern Illinois, the cover selected for night roosts by female prairie chickens for their broods is usually in fields having fairly thin and low grass, sparse weed growths or open grassy spots. Nearly grown roung birds sometimes use for roosts small patches of thin, uncut redtop. On cool evenings the young frequently seek a furrow, wheel track or other depression for protection from the weather. 
In autumn and winter the birds select redtop stubble, idle grasslands or low weed growth, sometimes only 2 or 3 inches tall, fig. 9. On windy or cold evenings the adult birds, as well as the young, often select slight depressions or furrows for protection.

Nesting Cover.-During the summers of 1935 and 1936 all types of nesting cover on the t-square-mile Jasper County area were searched carefully to determine as accurately as possible the actual use of each type of cover.

Although prairie chickens in southeastern Illinois nest in a variety of sites, they show a preference for short grass cover with scattered growths of brambles and herbaceous plants such as are found in waste areas of bluegrass, Poa pratensis Linnaeus, and old stands of redtop, Agrostis alba Linnaeus. The sites of 39 nests under observation on and near the Jasper County study area may be classified as follows.

Redtop Fields.-Redtop, which during the period of this study occupied nearly 30 per cent of the Jasper County study area, presents a larger acreage of potential nesting cover than any other kind of vegetation. As previously intimated, new seedings apparently are used less often than old stands. In 1935, when much farm land had been out of cultivation for 2 or more years, because of low agricultural prices, numerous idle fields had developed sufficient grass and dead vegetation to make them attractive nest sites. Consequently, redtop was less generally used then than in 1936 and later when some of the idle fields were put back into cultivation. Fourteen of the 39 nests under observation were in redtop fields.

Fallow Fields and Pastures.-In addition to fallow fields, this classification includes a small acreage of pasture land, amounting to about 1 per cent of the total study area, pasture land invaded by brambles or having spots of low sedge growth. 'The remaining pasture land is almost without exception badly overgrazed and therefore of no use for nesting sites. During the nesting study, about 18 per cent of the total land in the vicinity of the Jasper County area consisted of fallow fields or lightly grazed pasture. Twelve prairie chicken nests were found in this type of cover, of which 7 were in fallow fields, 3 were in pastures and 2 were in fallow fields that had been planted to corn the previous year.

IV aste Grassland.-Small waste areas chiefly of bluegrass, not subject to grazing or farming for several years, averaged at the time of this investigation about 2 per cent of the total land acreage on the study area. 'This was the most intensively used type of nesting cover from the standpoint of density of nests. Thirteen nests were located in these areas, of which six were on low ditch banks, five were on an abandoned railroad bed, one on a roadside and one in a fencerow.

The choice of particular nesting sites in the waste grassland type was sometimes difficult to explain. Borders of back roads constitute the greatest area of seemingly favorable nesting cover of this type, but apparently they were little used. Ditch banks used as nesting sites were usually nearly level with the adjoining fields, and often narrow. It is evident that the stage of plant succession is an important factor in choice of site. The distance of the

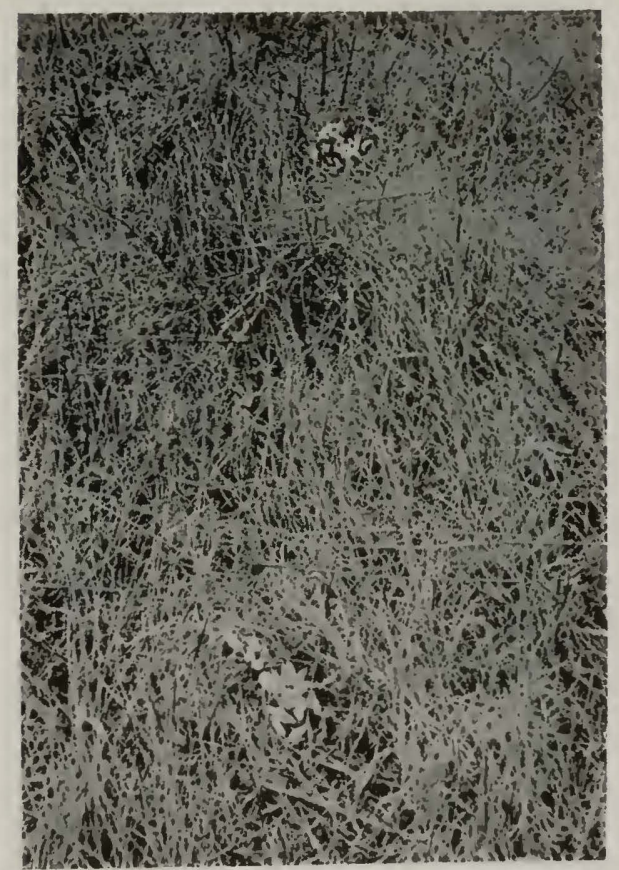

Fig. 9.-Night roosts of two southeastern Illinois prairie chickens in short grass and weeds, Feb. 9, 1940. Prairie chickens usually select slightly taller vegetation in sheltered spots for their winter roosts. 
Tahle 1.-Types of nesting cover used by prairie chickens in Jasper County, III., chiefly in the summers of 1935 and 1936 .

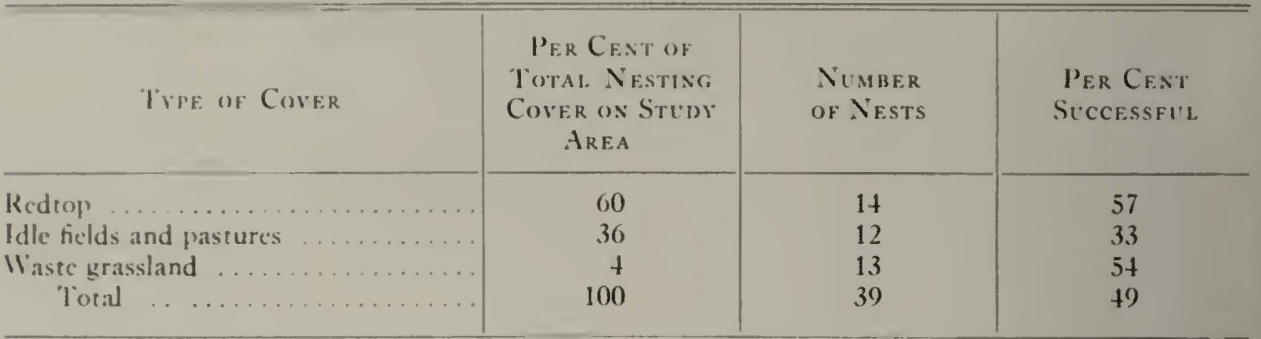

cover from booning grounds also apparently influences the choice.

Reference to table 1 show's that, in this study, success of nests in redtop fields and in waste areas was higher than in idle fields. Although no conclusions can be drawn from the few records presented here, there is some basis for believing that nest losies in idle fields are often relatively high, due to the fact that these areas frequently are plowed after nesting has hegun. Moreover, losses resulting from predators are apparently higher in fallow fields than in redtop because the former more frequently contain dens of furbearers whose early spring hunting activities include nearby open areas.

\section{Nesting Habits}

As indicated above, prairie chicken nests in southeastern Illinois are located usually in grassy sites, sometimes without any other vegetation for cover, but more often

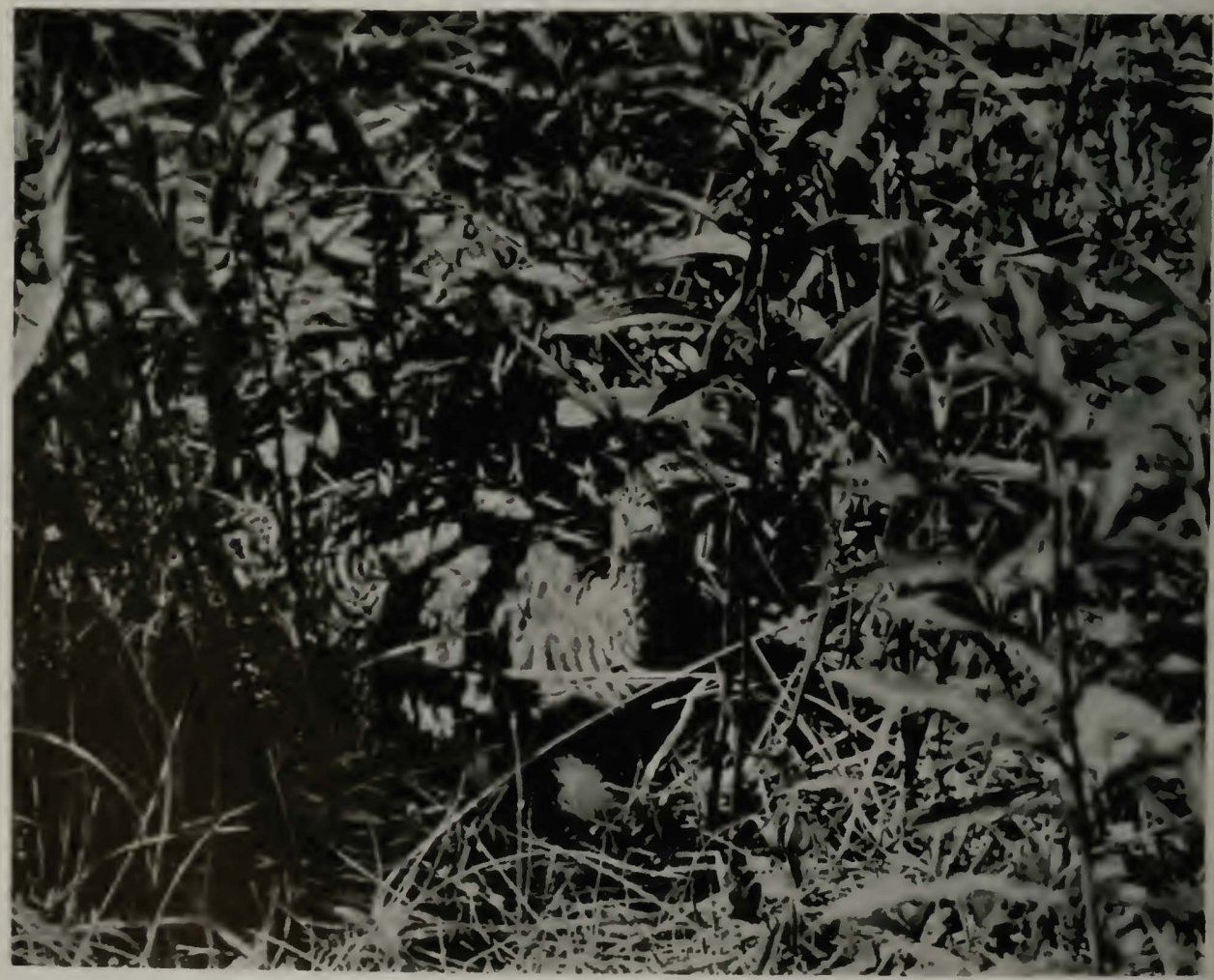

Fig 10.-Female prairie chicken incubating her eggs in a nest partly concealed by a growth of ironweeds. 
with a bramble or a few herbaceous plants serving as overhead cover, frontispiece and fig. 10. Some nests are in thin growths of grass under a single stem of dewberry or rose that offers scant concealment,
Nine of 23 prairie chicken nests reported on by Hamerstrom (1939) in Wisconsin were within a half mile of a booming ground, and 10 were between a half mile and a mile and a quarter. The distances

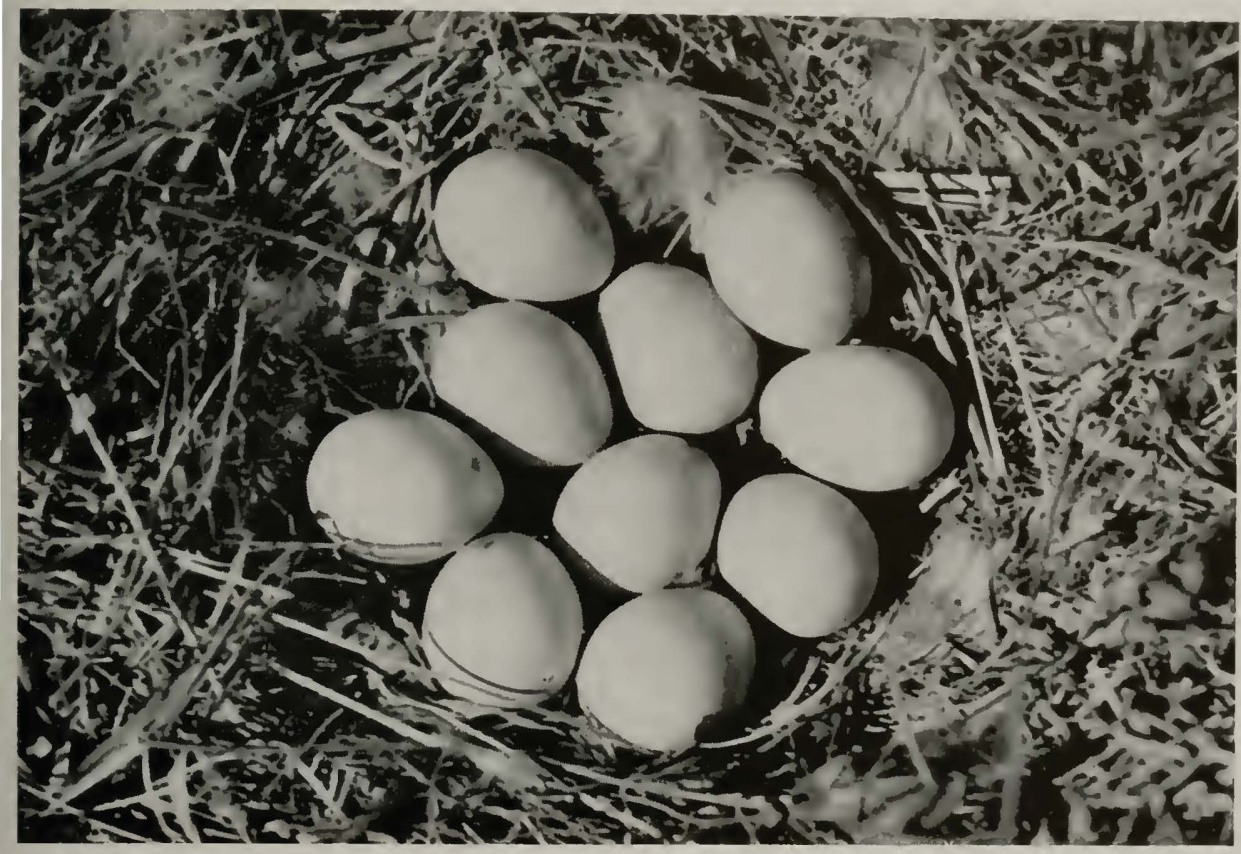

Fig. 11.-Prairie chicken nest containing 10 eggs. The overhead canopy of bluegrass and dewberries was removed while the nest was being photographed.

while others have been found in the thick grass growth of old stack bottoms in redtop fields. Tall and rank weed growth apparently is not attractive to prairie chickens.

There appears to be a definite tendency for field nests to be situated within a few feet from the field margins. Not infrequently nests are found close to hedges or small trees along field margins or streams. Gross (1930), working in IVisconsin, found that on rare occasions nests are surrounded by trees of considerable size.

Prairie chicken females occasionally lay eggs in the nests of others of their kind, making up clutches of 20 or more eggs. The largest observed clutch believed to have been laid by one prairie chicken consisted of 16 eggs. The average size of 12 clutches, most of them seen in 1935 and 1936, and each clutch laid apparently by a single female, was 12.3 eggs. Fig. 11 shows a nest containing 10 eggs. from the other + to the nearest booming ground were unknown. In southeastern lllinois, where booming grounds are apparently much closer together than in the area in which Hamerstrom worked, the relationship of outlying nests is difficult to determine, but a definite tendency for nests to be grouped close to booming grounds was evident. The great majority of nests found on the Jasper County study area were within a radius of a quarter mile from the nearest booming ground; and wherever favorable nest sites were available on the Jasper County area a number of nests were found hetween 150 yards and 330 yards from a booming ground.

\section{Nest Concentrations}

Reports received from observers who recall conditions in southeastern Illinois 60 years or more ago indicate that large numbers of prairie chicken nests were 
sometines found in relatively small areas of nesting cover. Leopold (1933) mentions reports of former concentrations of nests in lowa. Johnson (193t) recalls a tract of about 10 acres of unbroken prairie near his home in Marshall County. Minn., where numerous prairie chicken nests, both old and new, were disclosed by a spring fire. These instances seem to be associated with fairly high populations and the occurrence of areas of choice nesting cover in localities in which much of the nesting cover had deteriorated as the result of agricultural practices. Nevertheless, in view of the observed preference of prairie chickens for certain vegetative types, it does not seem unlikely that nest concentrations may sometimes have occurred on the virgin prairie.

Although there was ordinarily no marked tendency for nests to be grouped together on the Jasper County study area, in at least one instance favorable nesting cover was responsible for the selection of a number of nesting sites within a limited area. In 1936 a booming ground used by about 7 males was located slightly more than an eighth mile from a small area of grassland, the margins of which were being invaded by blackberries. This tract, about 200 yards long and less than 100 yards wide, approximately + acres, included part of a lightly grazed pasture, a small fallow area and a strip of bluegrass along a creek. A search of this cover in June revealed four prairie chicken nests. Since no other nests were found nearby, it seems probable that nearly all, if not all, of the females in that locality were nesting in this small area. By May 1, in Jasper County, redtop has usually made sufficient growth to invite nesting, and after this there is probably less tendency for nests to be grouped in small bluegrass areas.

\section{Causes of Nest Losses}

Although of 39 nests under observation in Jasper County, 19, or 49 per cent, were successful, table 1 , it is significant that of the 20 unsuccessful nests 7 were abandoned or destroyed early in the season when only one to three eggs had been laid. There is considerable reason to believe that in such cases new nests are begun within a few days. Indications are that in southeastern Illinois a compara- tively high percentage of the females finally bring off broods successfully, because of renestings and a general increase of the quality and quantity of nesting cover as the breeding season advances.

It is of interest to note in this connection that, although field studies in 1935 and 1936 showed an occasional attempted renesting as late as July, there was no evidence that nesting attempts begun after the first week in June added a significant number of young birds to the crop. Apparently redtop cutting during July finds the hatching period nearly over and most of the nesting attempts ended, fig. 7.

The causes of 19 out of 20 nest failures were known or could be determined from evidence at the nest. Predators destroyed seven nests, desertion was responsible for the loss of six, farming operations destroyed five, one full clutch was apparently infertile and one nest from which three or four eggs had disappeared was listed as failing for an undetermined cause.

Predators.-Clutches laid in April in poor cover were found to suffer fairly high losses from crows and furbearers. Thirty-five per cent of the nest losses observed in this study were due to predators. In addition, broken shells, showing beak or teeth marks, were frequently found on the ground, and the nests from which they had come could not be located. Egg shells were sometimes found along hedges where they had apparently been dropped by crows. In southeastern Illinois, possibly crows take more eggs than any other one species, but, since prairie chickens frequently lay an egg or two in exposed places early in the season, it is difficult to say how much of the crows' activity is actual nest robbing.

Furbearers hunting widely over meadows and crayfish flats in early spring destroy a number of exposed nests. Apparently, skunks, opossums and, on occasion, minks and raccoons are guilty of nest robbing.

The role of snakes as nest robbers in this region is undetermined, but probably certain species take some toll.

In southeastern Illinois, growth of vegetation by early May usually restricts the feeding areas of most predatory species, and, as a result, nest losses from predators become of minor importance. Under these circumstances, the effect of egg predation 
seems to be chiefly to delay the nesting season.

Desertion.-Nest desertions in the Jasper County study area occurred chiefly early in the nesting season, and usually when only a small number of eggs had been laid. Apparently at the beginning of their nesting efforts the females are very wary and desert as the result of even slight disturbances. Later, when the incubation period is well under way, they do not desert their nests readily when disturbed.

Farming Operations.-Plowing of grass or idle fields in May and June for corn or soybeans is the chief nest hazard to Illinois prairie chickens from agriculture. However, spring burning of idle fields in 1936 was known to destroy Jasper County quail nests and doubtless was responsible for considerable loss of prairie chicken nests. Fortunately, burning has not been widespread since that year, when a large acreage of idle land was put back into cultivation.

Failure to Hatch.-Romanoff, Bump \& Holm (1938) state that fertility of eggs of upland game birds depends on the conditions of mating, the health and activity of male and female birds, and upon several other physiological and environmental factors. These authors point out also that the hatchability of fertilized eggs is dependent on their inherent vitality and nutrition and the environmental conditions of incubation. They found experimentally that the critical stages during which death of the embryos of pheasants, grouse and quails occurs most frequently are the fourth, the twelfth and about the twenty-second days of incubation.

Field evidence as to the fertility of prairie chicken eggs, the mortality of embryos and the effect of environmental conditions on the hatching of eggs is limited because of the relatively small number of nests observed. Only one clutch that was apparently incubated normally failed entirely to hatch, in this case seemingly hecause of lack of fertilization of the eggs. In two clutches nearly ready to hatch, known to have been exposed for several hours during periods of high air temperature and low humidity in each case, the majority of the young failed to emerge from the shell probably because of drying of the egg membranes. In 12 clutches judged to have undergone normal incubation, approximately 93 per cent of the 148 eggs hatched.

\section{Weights}

While trapping prairie chickens in southeastern Illinois in January, 19+0, Robert E. Hesselschwerdt, then employed by the Illinois Natural History Survey on Federal Aid in WVildlife Restoration Act projects, and Lynn H. Hutchens, then of the Forest Preserve District of Cook County, obtained the weights of 27 live, adult birds. The prairie chickens were in good condition, but some of them had been held in the traps for 10 or 12 hours before being weighed and had undoubtedly lost a few ounces.

The live weights obtained by Hesselschwerdt and Hutchens are as follows: average weight of males (20 specimens), 2 pounds $t .7$ ounces; heaviest male, 2 pounds 13.6 ounces; lightest male, 1 pound 15.2 ounces; average weight of females ( 7 specimens), 1 pound 12.5 ounces; heaviest female, 1 pound 15.2 ounces; lightest female, 1 pound $6 . t$ ounces.

\section{POPULATION STUDIES}

It was recognized at the outset of the present study that knowledge of at least the gross aspects of the behavior of prairie chicken populations in 11 linois was necessary in order to outline an adequate management program. This recognition led to the collection of a large number of population records, including field notes and reports received from qualified observers in different parts of the Hllinois prairie chicken range. $1 \mathrm{n}$ addition, fall, winter and spring censuses of the birds on the 2.560-acre study area in Jasper County were conducted each year from autumn of 1935 through the spring of $19+2$.

Prairie chicken population trends in northern Illinois are discussed elsewhere in this report. This section deals with the behavior of chicken populations in the principal range in southeastern Illinois.

Although censusing of the study area during three different seasons yielded useful information on movements and population densities of prairie chickens, it became evident that the fall and winter censuses were less reliable as indices of 
population trends than the booming ground censuses taken in April. For example, the study area proved to be a fatvorite wintering ground for prairie chickens, and each year, in early winter, an influx of birds occurred from nearby farms, causing the population level there to rise athove that of the surrounding range. In autumn the relatively high mobility of chicken flocks caused some variation from day to day in the number of hirds present on a given area of farmland,

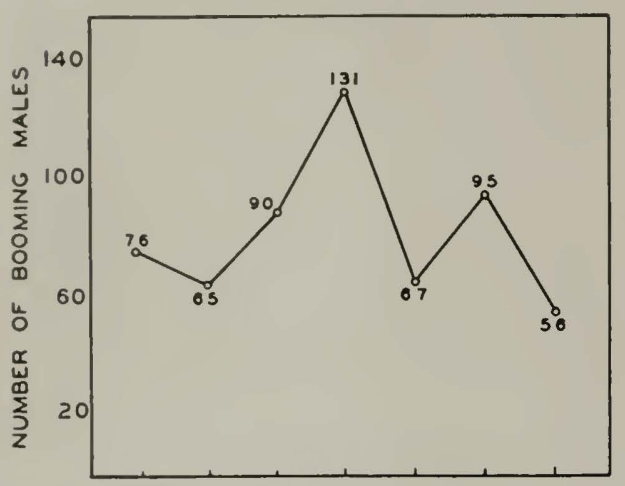

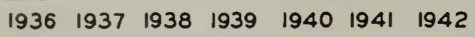

Fig. 12.-Trend of male prairie chicken populations on a 2-by-2-mile area in Jasper County, 1936-19+2, shown by booming ground censuses.

although the figures obtained during the fall censuses were undoubtedly more nearly representative of normal populations than those from the winter censuses. 'The fall censuses, taken annually from 1935 through 19+1, usually in late October or early November, showed an average population during the 7-year period of 179 hirds present on the area. The largest number of birds shown by any fall census was 255 , in 1938, and the smallest numher was 1+1, in 1939. These figures represent a variation in fall population densities of from about 1 bird per 10 acres to 1 bird per 18 acres. 'The average was approximately 1 bird per $1+.3$ acres.

The results of the censuses of inale birds on the booming grounds of the Jasper County study area are shown in an accompanying graph, fig. 12.

Since the number of inales on any particular booming ground is never constant throughout the season, every effort was made to take the census at the height of the booming season, usually in late April. Hamerstrom's (19+1) work clearly shows the need for eare in this respect. 'The booming census is subject to criticism in that it does not include the female birds; our efforts to determine sex ratios by trapping in late winter were unsuccessful due to the fact that a disproportionately large number of males were found to enter the traps. Nevertheless, field experience indicates that the census of booming males provides a usable and reasonably accurate index of local prairie chicken populations.

Davison (1940) used the booming ground census extensively in connection with his study of the lesser prairie chicken, Tympanuchus pallidicinctus (Ridgway), in Oklahoma. By comparing results obtained on census areas of different sizes, he concluded that the minimum area that could be censused as representative of any locality is 2 by 2 miles, and that census figures from areas 3 by 3 or + by + miles are more dependable.

The Jasper County census area, 2 by 2 miles, represents the smallest unit indicated by Davison's study as representative. The census was hegun there in 1935 to determine population trends in an area for which weather records and field studies on subjects related to the welfare of prairic chickens were available. Since the distribution of these birds is spotty in the mixed prairie and woodland districts of southeastern Illinois, it seemed advisable to confine the census to a relatively small area lying within the better range.

It is of interest to note that there was considerable similarity between the population fluctuations on the study area as shown by booming ground censuses and the fluctuations indicated by field records and reports from other parts of the southeastern Illinois range. For example, a decrease in the fall of 1936. corresponding to that indicated by the 1937 booming ground census of the Jasper County area, was reported to the writer by a number of observers throughout southeastern Illinois. In Missouri, Bennitt (1939) reported a decrease of prairie chickens in 1936. The "high" of 1938 was amply" confirmed for other localities in southeastern 1 llinois, as well as the study area, by field observations, by reports received from farmers and hunters, and by subsequent agitation for an open season. The 
population decline of 1939 , shown by the $19+0$ booming ground census, was marked by the absence in the fall of 1939 of the numerous large flocks seen in various parts of southeastern Illinois during the previous fall and winter. Surprisingly, on the study area, where the booming ground census of the spring of 1939 had shown 131 male birds present, the census taken the following fall showed a total of only $1+1$ birds of both sexes. Although the foregoing records indicate considerable variation in prairie chicken populations from year to year, when several consecutive seasons are considered there is no indication of recent major changes in the average density of these populations in the main parts of the range in southeastern Illinois. Undoubtedly, in recent years, there has been an increase in the total number of prairie chickens in this region, but this is due to extensions of the range into unoccupied territory rather than to building up of local populations.

Prairie chickens have been found to undergo cyclic fluctuations over a wide area in their acquired range in the northern Lake States (Leopold 1933), but relatively little evidence has been published on the subject of cycles in the Central States. Bennitt (1939) states that the type of population fluctuation of prairie chickens in Missouri is uncertain; it seems doubtful to him if Missouri birds are cyclic. Leopold (1931) cites a record of high chicken populations in Crawford County, southeastern Illinois, about 1920, but elsewhere in the same publication he states: "The question of early cycles must be left unanswered for Iowa, Minnesota, and Illinois. In Indiana, while the early behavior is unknown, there is a clear and convincing record of one fluctuation which I have called the 'comeback of 1912.',

That the increase of prairie chickens reported in Indiana in 1912 extended into Illinois is indicated by the following quotation from Forbes (1912): “. . . prairiehens - thanks to our protective laws-are now to be seen in at least seventy-four counties, so abundantly in some that farmers are beginning to protest against their further increase because of the amount of grain which they devour." As previously: mentioned, this gain proved to be a temporary one.

The average length of cycle of the prai- rie chicken and other grouse in the northern tier of states and Canada is believed by Leopold (1933) to he about 10 years. If the high populations reported in Illinois in 1912 and 1920) are to be regarded as manifestations of a cycle, another "high" would then be expected to occur about 1930. The writer has received reports from a number of observers indicating the reappearance at about this time of prairie chickens in certain southeastern Illinois localities from which the birds had previously been absent. However, these reported extensions of prairie chicken range may have been due to the improvement of local habitats since, as the result of low agricultural prices, large acreages of farmland were then lying idle.

The marked increase of prairie chickens in southeastern Illinois from 1936 through the breeding season of 1938 was plainly not related to changes in the habitat, since it occurred during a period when much idle land was being put back into cultivation. Viewed in the light of the two previously recorded high periods, the increase of chickens in 1938 suggests the possibility of the recurrence of a cyclic "high." It is of some interest that the 1938 peak occurred 26 years, or somewhat less than the equivalent of three average cycles of northern grouse, after the "high" of 1912. The 1938 peak was followed by an abrupt decline the next year. Population densities have fluctuated somewhat irregularly since 1939, but they have not again reached the 1938 level.

Records on fluctuations of cottontail rabbit populations obtained by members of the Natural History Survey staff give good evidence that this animal is subject to cyclic fluctuations in Illinois. In the northern tier of states, the cottontail cycle has been found to correspond rather closely to that of the prairie chicken. It may be noted that cottontails increased rapidy in central and southern Illinois during the 1936-1938 period, but they did not reach a peak until 1939, the year following the peak of prairie chicken populations, when exceptionally large numbers of rabbits were evident. Thereafter, rabbits declined steadily and were generally scarce in the central and southern parts of the state in $19+1$ and $19+2$. The lowest count of male prairie chickens on the Jasper County area was in the spring of $19+2$. The re- 
sults of the $19+2$ hooming ground census are sulject to some doubt, however, since prevailing windy weather during the 2 divs when the count was made may have prevented the appearance of some males on the booming grounds. Time and travel restrictions in $19+2$ prevented later rechecking.

Although from the present study there is little evidence of the sustained rises and declines which seem to characterize the grouse cycle in the northern tier of states and Canada, the population records so far obtained suggest the possibility that southcastern Illinois prairie chickens are subject to some degree of cyclic Huctuation.

Reports of game technicians at a seminar on prairie chickens held at Urbana, 111., in December, $19+0$, showed that prairie chickens had increased during the previous + or 5 years in nearly all central states from Kansas to Indiana. A plan agreed to at this meeting to pool population data gathered over a period of years by game investigators working in several midwestern states offers a means of eventually reaching conclusions as to the behavior of populations of greater prairie chickens in the southern part of their range.

\section{MORTALITY CAUSES}

'The causes of prairie chicken mortality in Illinois, as indicated by field studies, include predators, pathological factors, accidents and illegal hunting, as well as certain hazards that are peculiar to the infant and juvenile periods.

\section{Juvenile Hazards}

'To determine the amount of annual reproduction of partridges, Middleton (1935) in England used the ratio of young to adult birds found by a midsummer census taken over a series of years. This method was used to some extent with greater prairie chickens in southeastern Illinois. "The census for the third week in July, 1935, on the Jasper County area showed 80 adults and 110 young, or 1.38 young per adult. A similar census in 1936 showed 95 adults and 70 young, or $0.7+$ young per adult. These results indicate a significant variation in the number of young birds present in midsummer, a variation due apparently to a number of influences. Weather during the breeding and hatching period may influence reproduction and the survival of young, but this situation is a complex one in which the various phases of the reproductive cycle must be considered, as well as the possible effect of weather on cover, food and parasite dissemination. We have insufficient data for conclusions.

It is evident that mortality among very young birds may be high. For example, in the summers of 1935 and 1936, the average number of eggs was 12.3 in 12 full clutches that underwent normal incubation. 'The average size of broods at hatching was $11 .+$ young. However, at an average age of about 5 weeks, 32 broods in which the total number of young could be determined with reasonable accuracy showed only 6.2 young per brood, indicating an average loss for the two seasons of approximately +6 per cent during the infant and early juvenile periods. It is probable that the heaviest losses occurred when the young were only a few hours or days old.

Although, because of small samples, this figure can be regarded as only approximate, it assumes a heavy loss of weak and inexperienced young similar to that reported in certain other gallinaceous birds. It is of interest to note that Lehmann (1939), working in eastern Texas in the summer of 1937, found a loss of about 50 per cent of young Attwater's prairie chickens, Ty'mpanuchus cupido attuateri Bendire, during the + weeks after hatching.

Actual records of the fate of young prairie chickens are extremely difficult to obtain. Occasionally one or more eggs fail to hatch until after the brood has left the nest. A few young die in the nest from weakness or trampling; any weak or subnormal birds undoubtedly soon fall behind when the female leads the brood away from the nest. Exposure to the direct rays of the sun or to chilling temperatures, resulting from flushing of the female, may be fatal to very young birds. Enemies, accidents, straying and various other hazards add to the toll of the young; for example, a 2- or 3-day old prairie chicken found with its skull broken in by a large, but unidentified, bird. As the young prairie chickens become stronger 
and more experienced, the losses among these birds drop sharply.

\section{Predators}

It has become evident in recent years, as a result of numerous studies on the relation of predatory species to game species, that predation has a less important role in the control of game populations than was formerly supposed. Game populations often fluctuate widely, apparently to a large extent without reference to the presence or absence of enemies.

Although there is variation in feeding habits and food preferences, predatory birds and mammals tend strongly to take what is abundant and easy to obtain. 'This tendency is reflected by the fact that in lllinois during most of the year rodents bear the brunt of the feeding activities of the great majority of the larger predatory species.

None of the small furbearers appears to be an important predator on young or adult prairie chickens in the gray soil prairie region of the state. The predatory species most conspicuous by reason of numbers or of apparent ability to inflict losses on prairie chickens in this region are the Cooper's hawk, the marsh hawk, the horned owl and the red fox.

Cooper's Hawk.-The Cooper's hawk, Accipiter cooperi (Bonaparte). feeds primarily on birds and is the species most often guilty of taking game birds and poultry in Illinois. McAtee (1935) reports that game birds were found in 31 of the 261 stomachs of Cooper's hawks examined by the U. S. Bureau of Biological Survey. Stoddard (1931) regards this hawk as probably the worst natural enemy of the bobwhite in the southeastern part of the United States.

This "blue darter" is not especially common as a nesting species in the prairie districts of southeastern Illinois. IVhere it occurs in this region during the spring and summer, its depredations on prairie chickens seem to be confined chiefly to the immature birds. If Cooper's hawks are present in any numbers on refuges or management areas, control measures will probably be called for in the case of this species.

If control of Cooper's hawk is undertaken, it should be with full knowledge of the appearance of this hawk, since it is a notably secretive species and is rarely bagged by hunters unfamiliar with its habits. Promiscuous shooting of hawks and owls is likely to do more harm than good, since the slower, more conspicuous species are usually those that feed chiefly on rodents. It should be remembered that redents, especially ground squirrels and field-inhabiting rats, may be serious enemies of nests and young of game birds, as well as destroyers of farm crops. Most predatory birds can well be encouraged for their assistance in the control of these animals.

Marsh Hazk.- The marsh hawk, Circus hudsonius (Linnaeus), is a common summer resident throughout the gray soil prairie region of Illinois. Because, during the period of intensive field work in southeastern Illinois, marsh hawks hunted regularly over fields occupied by coveys of prairie chickens, special efforts were made to determine the extent to which these hawks preyed on the young chickens. Examination of many pellets in the field, observations on hunting marsh hawks, and studies of prey brought to the young hawks by the adults, did not give evidence of the killing of appreciable numhers of prairie chickens by these hawks.

Errington \& Breckenridge (1936) report that young pheasants made up slightly more than + per cent of the total number of food items taken by marsh hawks in the lowa pheasant range during the summer of 1935 . 'That such predation does not have a serious effect on the pheasant crop is indicated by the report of Errington \& Hamerstrom (1937) that, during their Iowa pheasant studies, broods of young pheasants in areas where marsh hawks were rare shrank in size at the same rate as did broods in areas hunted by marsh hawks.

Randall (19+0) found that marsh hawks caused about 10 per cent of the total mortality of juvenile pheasants on a study area in Lehigh County, Pa., where both marsh hawks and pheasants were common. 'The loss amounted to 1.3 per cent of the population of young pheasants.

Grange (19+1), reporting on the progress of a grouse investigation in central IVisconsin, tentatively concluded that "Marsh Hawks are probably a consistent but small factor in the mortality of young 
grouse in our area." He pointed out that destruction of striped spermophiles and other potential enemies of prairie grouse by marsh hawks may counterbalance the harm done in preying on the young birds.

Leigh (1939) summarizes his records of the food brought to a family of young marsh hawks under observation in the Jasper County study area as follows:

During the period of observation, young (unidentified) song hirds, immature rabbits and meadow mice (Microtus) constituted the major portion of the bill-of-fare for the young raptors. Recognizable bird remains included three young Boh-white and two young Upland Plovers (Bartramia longicaula). As far as could be determined from feathers, pellets, and other fragments, no Prairie Chickens were brought into the young during the observation period.

Although the marsh hawk may occasionally take a young prairie chicken, our observations on the summer feeding habits of this hawk in southeastern Illinois provide no evidence that it can capture prey as large as an adult prairie chicken, unless the chicken is crippled or otherwise incapacitated.

If control of the marsh hawk is indicated on game management areas or refuges for the benefit of game birds, it should be restricted to individuals that are known to be doing harm. McAtee (1935) sums up the economic status of the marsh hawk on the basis of 601 stomachs examined by the U. S. Bureau of Biological Survey as follows:

Probably the insect food of the marsh hawk may be balanced against that portion composed of the moderately beneficial snakes and frogs. The remainder of its subsistence is about equally divided between birds and mammals, the indication being that more harm than good is done in the destruction of the former and that the reverse is true in the case of the latter. The economic tendencies of the marsh hawk seem to be about evenly balanced, and the decision as to whether it should be interfered with should be based on local experience-but this should be actual experience or observation, not prejudice.

Buteo Hawks.-These large, soaring hawks, or "mouse hawks," Buteo spp., are relatively unimportant as enemies of prairie chickens.

Although the red-tailed hawk may now and then manage to capture full grown pratirie chickens on the ground, it is too slow to overtake these birds when they are in flight. The red-tail feeds to some extent on such potential enemies of game birds as ground squirrels, barn rats, crows and bull snakes, thereby probably compensating for occasional destruction of game. The bulk of its fond consists of rodents.

Red-shouldered hawks and rough-legged hawks rarely molest healthy game birds and may be useful on game areas because they tend to keep rodent populations in check and occasionally take weak or diseased game animals or birds that might serve as sources of infection.

Great Horned Owl.- The great horned owl, Bubo rirginianus rirginianus (Gmelin), a large and powerful predator, is usually regarded as a serious enemy of small game. Exhaustive studies by Errington, Hamerstrom \& Hamerstrom $(19+0)$ on food habits of this owl in Iowa and IVisconsin show that rabbits and hares are the staple items in the diet of this predator. It regularly eats smaller rodents, chiefly mice and rats, according to these authors. Passerine birds, poultry and game birds make up only a minor part of the total diet. Instances of conspicuous local predation on game birds are usually associated with environments overpopulated by the game species.

In southern Illinois, horned owls inhabit chiefly the more heavily wooded sections where prairie chickens are not plentiful. Consequently, predation seems for the most part to be confined to areas where woodland and prairie are well interspersed. Even there our evidence against this owl does not indicate serious predation on game birds.

Stoddard (1931) regards the great horned owl as beneficial on quail preserves in the southeastern United States because of the assistance it gives in keeping skunks, opossums, cotton rats and other enemies of the bobwhite within bounds.

On refuges or game management areas, particularly in the northern part of Illinois, elimination of individual horned owls may in some cases be necessary to protect concentrations of game birds, but a systematic campaign to eradicate these predators from prairie chicken refuges is not recommended.

Other Owls.-Although the northern 
barred owl, Strix raria r'aria Barton, approaches the horned owl in size, it feeds to a greater extent on mice and is less prone to take poultry or game birds. This owl is generally more common than the horned owl in the southern Illinois prairie chicken range. It sometimes hunts in the daytime and is the large owl most frequently shot by hunters. On the basis of intensive food studies, as well as field observations in Illinois, killing of these birds is not to be recommended except in the case of individuals that may form the habit of taking poultry or game birds.

Throughout the prairie region of Illinois, the short-eared owl, Asio flammeus flammeus (Pontoppidan), is encountered by hunters probably more often than any similar bird because of its habit of resting during the daytime, singly or in small groups, in weedy areas or stubble fields. Short-eared owls are attracted to fields in which mice are abundant, where they sometimes hunt by day. Their pellets usually contain little besides mouse fur and bones. These birds rarely nest as far south as south central Illinois; throughout the state they occur mainly as winter residents. Smaller than northern barred owls, they are not known to take game birds larger than a bobwhite or a Hungarian partridge, and these only rarely. The short-eared owl, the barn owl, Tyto alba pratincola (Bonaparte), and the longeared owl, Asio wilsonianus (Lesson), are highly beneficial to the farmer and should be fully protected.

Red Fox.-In recent years, the population trend of the red fox, Vulpes fulva (Desmarest), in the state has been generally upward. At present, red foxes can be classed as abundant throughout the prairie chicken range of southern Illinois. According to distribution studies made by Dr. Carl O. Mohr of the Illinois Natural History Survey, and based on trappers' records, the red fox population of the gray soil prairie region is somewhat higher than the average for the whole state.

Although no special study of fox food was attempted, field records obtained in southeastern Illinois during all seasons throughout a period of 7 years did not indicate that the red fox was particularly destructive to game birds in that region.

Errington's (1937) conclusion that pheasants, bobwhites and Hungarian part- ridges in Iowa are subject to a temporary increase in vulnerability to general predation at the beginning of the mating and breeding season is in agreement with our observations on prairie chickens. Nevertheless, prairie chicken losses at this season did not reach serious proportions in the Illinois area studied.

Although some of the six instances of apparent desertion of nests listed in the section on nesting may possibly have been due to death of the female, it is of interest to note that no instance of killing or injury of a female directly on the nest by a predator was evident in the 39 nests under observation. Probably reduced emission of scent during the incubation period, which occurs in the prairie chicken and certain other gallinaceous birds, is in part responsible for the relative safety of the nesting female. However, this affords only partial protection, as indicated by the fact that killing of the female on the nest by house cats or other mammalian predators is reported in the bobwhite (Stoddard 1931) and the Hungarian partridge (Yeatter 1934).

Errington (1937) says of the fall, winter and early spring feeding of the red fox in Iowa:

During fall and winter, the brunt of red fox feeding pressure is borne by mammals, notably mice and rabbits. Occasional passerine birds, ring-necked pheasants, and bobwhites are taken, and these and other species are freely eaten as carrion when carcasses are found in fields or along highways.

Domestic chickens eaten are probably carrion for the most part at this season; many farmers habitually dispose of their dead chickens by throwing them on the manure spreader, and the carcasses thus become available to various creatures, including foxes. It often happens that foxes bite off and swallow only the heads or feet of carcasses of this sort that they may discover. With the coming of spring and the pupping season, mice and rabbits continue to be the main staple foods, but other forms receive more attention, apparently in proportion to their increased availability. Migratory sparrows, blackbirds, meadowlarks, etc., yield some toll; and ground squirrels are captured as they leave hibernation for the dangers of active life.

Examination of fragments and feathers around fox dens, of fox scats and of various "kills" of game birds found in the 
field during the investigation gave relatively few indications of fox predation on prairie chickens among several hundred items of food. Nevertheless, experience may show that control of fox populations is desirable on refuges or game management areas where special efforts are being made to conserve and increase prairie chickens or other game birds. The comparative abundance of both chickens and foxes in southeastern Illinois, however, is good evidence that the fox does not constitute a serious menace to these birds in good chicken habitats.

Other Predators.-Evidence is mounting from various studies that ground squirrels may be important as destrovers of game bird nests as well as their young. Grange (19+1), working in Wisconsin, reports several instances of capture and killing of very young domestic chickens by the 13-striped ground squirrel, $\mathrm{Ci}$ tellus tridecemlineatus (Mitchill). Near Urbana, 111., in the summer of $19+2$, we found good evidence of the destruction of several pheasant nests by the Franklin's ground squirrel, C. franklinii (Sabine). Ground squirrels are much more common in the dark soil prairie districts than in the gray soil prairie and their control may present special problems on refuges in the northern part of the state.

Since the crow, Corqus brachyrhynchos brachyrhyuchos Brehm, is known on occasions to be destructive to young prairie chickens as well as eggs, large numbers of this bird on refuges during the nesting season would normally be undesirable.

Pilot black snakes, common black snakes, bull snakes, and possibly certain other snakes, are potential predators on the young and eggs of prairie chickens, but, as these forms feed extensively on rodents, their control should not be undertaken unless they prove actually harmful on refuges. The pilot black snake, Elaphe obsoleta obsoleta (Say), whose food was investigated by Uhler, Cottam \& Clarke (1939), is fairly common in Illinois, and the common hlack snake, Coluber constrictor coustrictor (Linnacus), which was found by Stoddard (1931) to rob quail nests in Georgia, is present in the prairies of southeastern lllinois. On the basis of the above studies, these forms might be expected to take some eggs or young of prairie chickens. 'The bull snake, Pitu- ophis sayi sayi (Schlegel), which is known from studies conducted by the Illinois Natural History Survey to take the eggs or young of waterfowl on occasions, is not numerous on the prairic, but might possibly cause minor losses of eggs or young of prairie chickens in the vicinity of wooded areas.

Domestic cats and dogs have often been reported as causing loss of eggs and young of game hirds. Although no instance of predation on prairie chickens by either cats or dogs was found in the present study, it is not unlikely that in southeastern Illinois both animals, particularly field-hunting cats, annually destroy a number of nests and young of prairie chickens.

\section{Parasites and Diseases}

Appraisal of the role of diseases and parasites in wildlife mortality is a difficult matter. Very weak animals often secrete themselves in thick cover where they are likely to be found, if at all, only some time after death has occurred; if partially disabled, they may he caught by predators and the evidence thus destroyed. Nevertheless, mounting evidence from field studies indicates that pathological factors may be responsible for greater losses of wildlife than has generally been supposed.

Since the prairie chicken is closely associated with domestic chickens and turkeys throughout its range in southeastern Illinois, the possible effect of poultry diseases and parasites on prairie chickens was considered an important part of the investigation. Gross (1930) reports that certain poultry parasites and blackhead, a disease fatal to domestic turkeys, were found in the prairie chicken in Wisconsin and in its close relative, the heath hen, Tympanuchus cupido cupido (Linnaeus), in Massachusetts.

During the Illinois investigation, a single prairie chicken showing the clinical symptoms of blackhead was found (Leigh 19+0). This bird, an adult male, was extremely emaciated, and died soon after being captured.

Although field studies in 1935 and 1936 did not give evidence of serious losses from pathological causes among adult birds, the finding of some unmutilated 
but partly decomposed carcasses of young birds during both years was considered as of possible significance from the standpoint of pathology. Previously, Leopold (1931) published a report of similar findings by an observer in Missouri, and Bennitt \& Nagel (1937) quoted game wardens and other observers, also in Missouri, as finding dead young during the drought summer of $193+$.

In a study of the parasites of Illinois prairie chickens, Leigh (19+0) autopsied $1+$ young and $\mathrm{I}+$ adult birds collected during field work in southeastern Illinois. Blood smears showed no indication of blood parasites. Smears of intestinal and caecal scrapings were negative for coccidia or other protozoa.

Internal parasites reported by Leigh included three species of tapeworms, two species of roundworms and one species of Acanthocephala. It is of interest to note that, although no tapeworms were found in the adult chickens, 10 of the $1+$ young birds were infested with tapeworms, which, in four cases, completely occluded the lumen of the small intestine for most of its length. Since the most intense infestations were by an apparently rare and hitherto undescribed species of tapeworm, there seems to be little relationship between parasitism and the presence of domestic poultry.

With respect to the possible effect of these parasites on the survival of juvenile birds, Leigh states:

Although it cannot be definitely stated at this time that the high incidence and heavy infestations with cestodes of a genus known to be pathogenic for other gallinaceous birds constitute a serious mortality factor in young prairie chickens, it is reasonable to think that the minimum effect of such intense parasitism in birds + to 8 weeks old would be a reduction in vitality which would open the way to secondary infections and render the birds more susceptible to predation or unfavorable environmental factors. Finding no cestodes in adult hosts would seem to indicate that the prairie chicken is susceptible to the new species of Raillietina during only the first few weeks of life.

\section{Accidents}

Accidents, chiefly those in which the birds strike wires or other objects while in flight, not infrequently cause the death or crippling of prairie chickens. The extent of such accidents, while probably greater than generally supposed, cannot be accurately determined because of the work of predators or scavengers that usually dispose of victims in a short time.

\section{Illegal Hunting}

Although the closed season in general affords fair protection, illegal hunting takes a moderate hut steady toll of prairie chickens in some parts of the Illinois range. Unfortunately, in areas where prairie chickens are numerous, public sentiment tends to be somewhat indifferent in regard to protection. Probably the most serious consequences of illegal hunting come through the loss of occasional birds from small, isolated colonies in the northern part of the state.

\section{Mortality and Populations}

The foregoing discussion of mortality factors will serve to emphasize the fact that, given proper environment, the prairie chicken has a reproductive rate sufficiently high to cope with predators, disease, accidents and other hazards. As previously pointed out, the welfare of this species in Illinois is dependent chiefly on suitable environment during the nesting period and while the hirds are very young. It is evident that prairie chickens can under certain farming systems maintain themselves for long periods in close contact with agriculture.

Hunting, under the short open season prevailing in Illinois a few years ago, added to other mortality factors, served to depress prairie chicken populations and undoubtedly constituted a limiting factor in marginal range; nevertheless, it seems apparent that the gun was not the primary cause of elimination of the prairie chicken from most of its range in dark soil prairie counties of the state.

\section{FOOD HABITS}

Field studies indicate that prairie chickens, particularly the young, feed to some extent throughout the day, but the main feeding periods are for about 2 hours in the morning, heginning a short time after 
Tuble 2.-Foods found in stomachs of 10 adult prairie ehickens collected in southeastern Illinois in late June, July and August, 1936 and 1937.

\section{Wild Seeds}

\section{Vegetalle Fool}

Buttonweed, Diodia leves Wilter......

Giant ragweed, Ambrosia trifida Linnaeus

Partridge pea, Cassia Chamaecrista Linnaeus

Pennsylvania persicaria, Polygonum pennsylvanicum Linnacus

I'ild mustard, Brassica sp.

P.lack bindweed, Polygonum Convolvulus l.innacus ........

Yellow foxtail, Selaria glauca (Linnacus) Beauvois ..........

Toul wild seeds

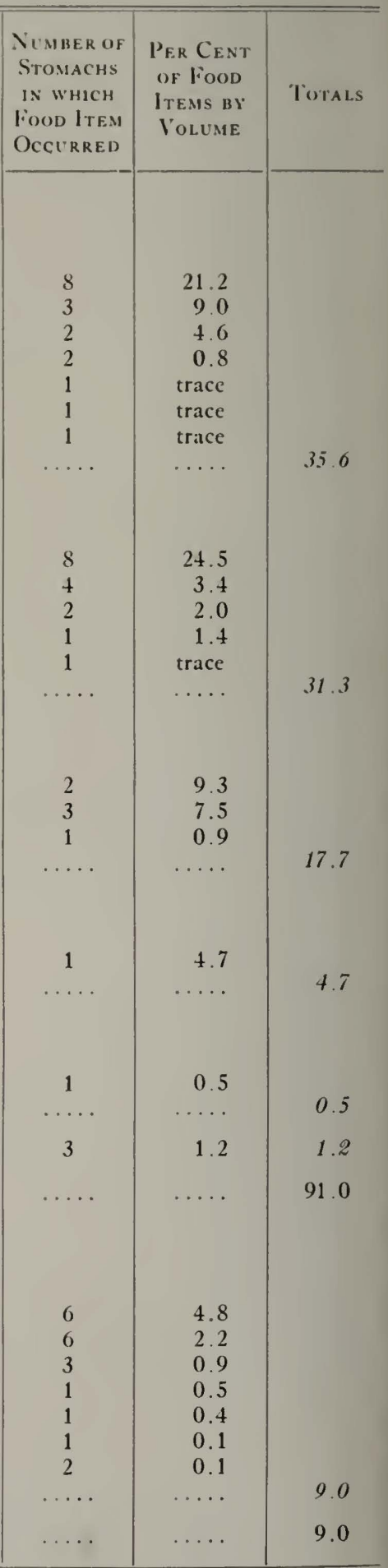

Dewberry, Rubus villosus Aiton

Panicle dogwood, Cornus paniculata L'Héritier de Brutelle.

Wild black cherry, Prunus serotina Ehrhart.

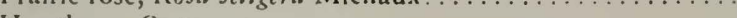

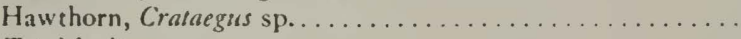

Total fruil

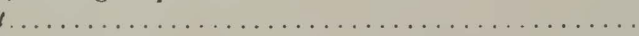

\section{Browse}

Flowering spurge, Euphorbia corollata Linnaeus...........

Goldenrod, heads and leaves, Solidago sp.................

Unidentified leaves.............................

Tolal browse.

Grain

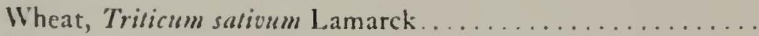

Tolal grain.

Mast

Acorns

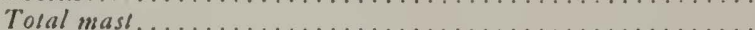

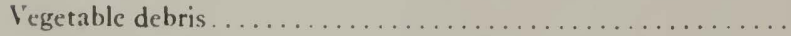

Total V'egetable food

Insects

ANIMAL fiood

Short-horned grasshoppers, Acrididae

Ground beetles, Carabidae.

leaf beetles, Chrysomelidae.

Snout bectles, Curculionidae

Beetles, unidentified....

Cutworms and army worms, Noctuida. . . . . . . . . . .

Insect pupae.

Tolal insects.

Total animal fiood.

Noctuidae. . . . . . . . . . . . .

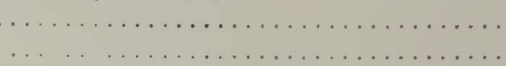


Table 3.-Foods found in stomachs of 14 young prairie chickens collected in southeastern Illinois in late June, July and August, 1936 and 1937.

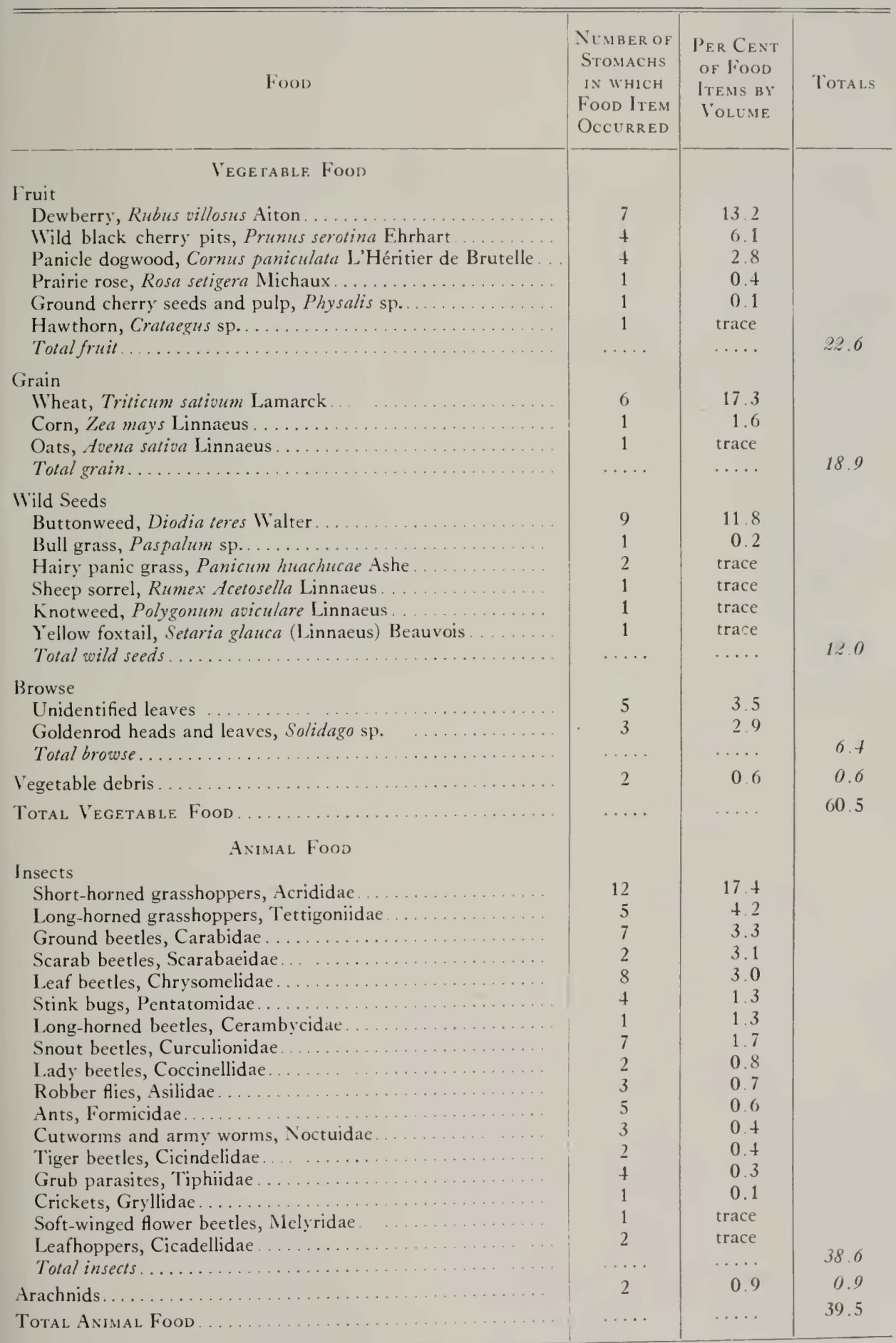


sumrise, and in the afternoon for an hour or more hefure sundown. In summer the adults and young have frequently been observed dusting along field margins early on clear mornings previous to feeding. () dark, raing days, the females and young are likely to be found sitting quiet- one-third of the food of chickens collected during the period of May to Octuber, inclusive.

Gross (Bent 1932) reported that 17 prairie chickens, collected mostly during the fall in IVisconsin, had eaten about 72 per cent vegetable matter and 28 per

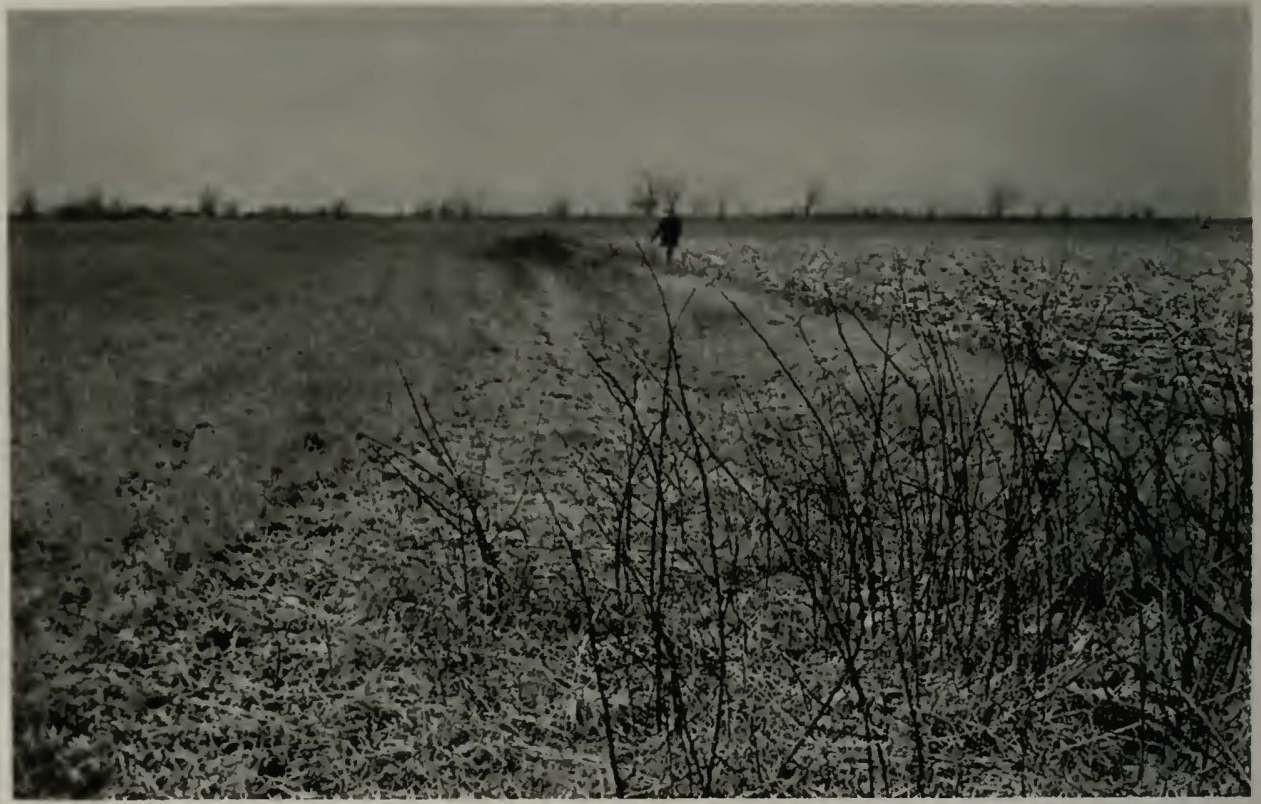

Fig. 13.-A cornfield, right, in which numerous prairie chickens fed in the winter of 1938-39, and nearby grassland used as cover.

ly along hedges well through the usual morning feeding period.

In the spring, the males appear to feed little until after the morning booming period.

Several workers have investigated the ford of the prairie chicken in the Middle West. Judd (1905) analyzed the stomachs of 71 chickens collected in the Mississippi valley during all months except July: The fool consisted of approximately +6 per cent seeds and grain, 25 per cent browse, including leaves, flowers and buds, $1+$ per cent animal matter, chiefly grasshoppers, 12 per cent fruit and about 3 per cent miscellaneous vegetable matter, mostly acorns.

About 31 per cent of the annual diet was grain, over half of which was corn. Nearly 15 per cent consisted of weed seeds, over half of which belonged to the smartweed family. The fruits eaten were chiefly rose hips. Insects made up about cent animal matter. Although more than 160 kinds of animal matter and vegetable matter were found in the diet, it was evident that a dozen items made up nearly 90 per cent of the food. Arranged in the order of percentages of all the food eaten, the 12 leading items were short-horned grasshoppers 26.7, ragweed 11.0 , oats 10.8, clover 7.7 , black bindweed 6.2 , acorns +.5 , greenbrier 3.6, dogwood 3.5 . crickets 3.3 , buckwheat 3.1 , bramble 3.1 and blueberries 2.t.

Schmidt (1936) observed during a study of the winter feeding habits of IVisconsin prairie chickens that buds, especially of birch, hazel and aspen, formed a large part of the diet of males in the northern counties of the state when temperatures were above zero, but that corn or other grain and weed seeds were taken regularly when the temperatures were below zero. He found that, in the southern IV isconsin counties, resident birds and 
migrant females appeared to feed on grain, weed seeds and buds through the winter.

Hamerstrom's (19+1) field studies and experimental feeding of prairie chickens in confinement showed that IVisconsin birds eat grains, weed seeds, browse and greens in autumn and winter, but throw greater emphasis on the value of cultivated grains, including corn, buckwheat, barley, oats and rye, as winter food.

Field observations show that waste soybeans, waste corn, fig. 13, and weed seeds form an important part of the winter diet of the prairie chicken in southeastern 1llinois. As a rule, prairie chickens do not eat shocked corn except during periods of deep snow. Although grain sorghums are not grown extensively in this region, during severe weather the birds readily eat sorghum in shocks, if it is available. They eat available weed seeds, as well as grains, throughout the winter and early spring. The crop of a recently killed female found on March 29, 1937, was full of soybeans. Winter droppings almost invariably contain quantities of grass and other green material. Fruits of rose and wild grape, as well as other persistent fruits, are in the diet to some extent during the winter.

Apparently budding is less common in Illinois than in WVisconsin. Prairie chickens have been ubserved eating buds from as early as Nov. 9 to early April in southeastern Illinois; however, so far as our records go, budding is not a daily practice. Probably green leaves of grass and herbaceous plants partially supplant buds in the diet at this latitude, as suggested by Leopold's (1931) observations in Iowa. Cottonwood is the chief browse species, but buds of red maple, elm, apple and probably several other trees and shrubs are included to some extent.

Samples of the summer diet of prairie chickens are illustrated in tables 2 and 3 , showing percentage by volume of various food items in crops and gizzards of 10 adult and $1+$ young birds taken in southeastern Illinois during late June, July and August of 1936 and 1937. As has heen shown by food studies of other gallinaceous birds, it is probable that the food

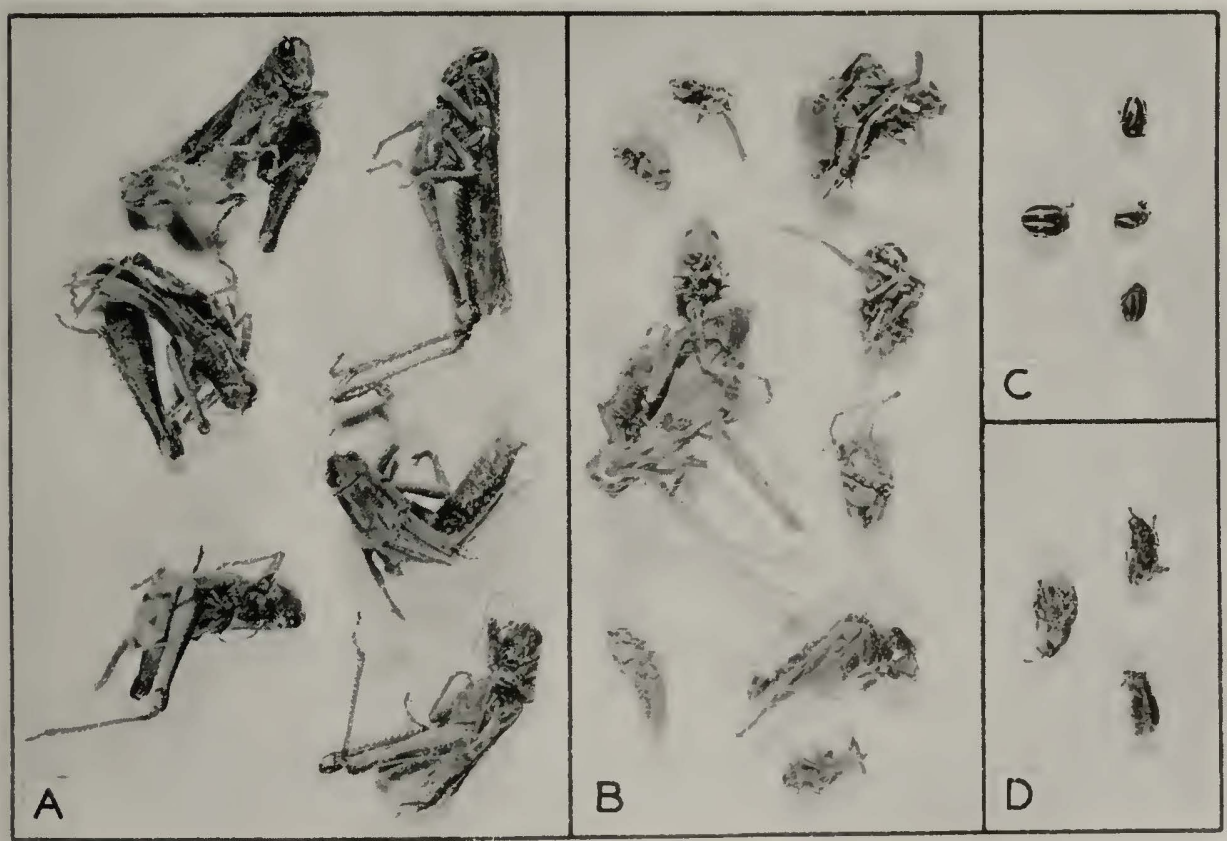

Fig. 14.-Animal matter found in the crop of a young prairie chicken (approximate age 10 weeks). A. Short-horned grasshoppers, Melanoplus differentialis. B. Short-horned and longhorned grasshoppers, including Neconocephalus robustus. C. Leaf-feeding beetles, Calligrapha similis and Cryptocephalus venustus. D. Imbricated snout beetles, Epicacrus imbricatus. 
uf very young prairie chickens consists almost entirely of animal matter, chiefly insects. During the period of growth, the diet gradually changes to seeds, succulent vegetable material, fruits and insects char- sisted chietly of waste wheat kernels, many of which had started to sprout.

Wild fruits, including those of dewberry, panicle dogwood and wild black cherry, were prominent in the stomach

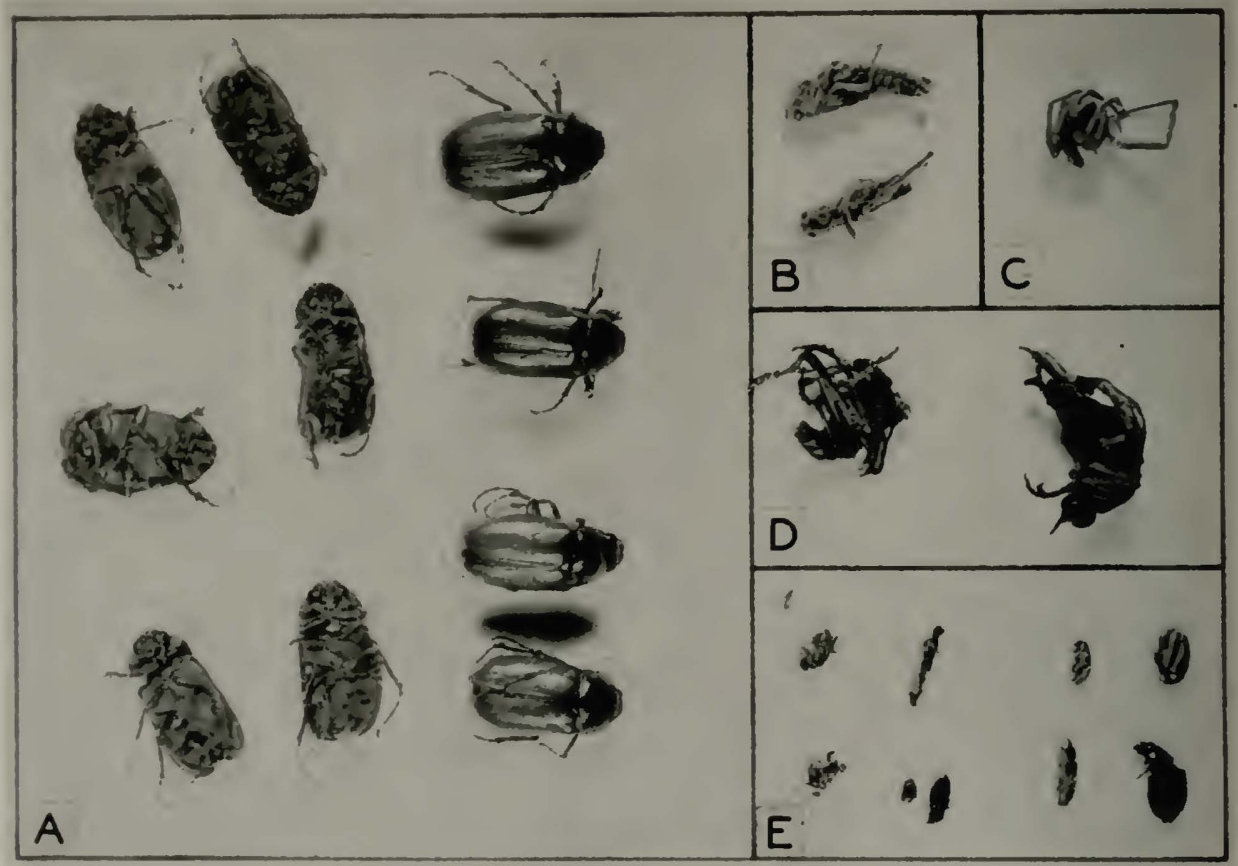

Fiø. 15.-Animal matter found in the crop of a young prairie chicken (approximate age 8 weeks). A. June beetles, Phyllophaga spp. B. Long-horned and short-horned grasshoppers. $C$. Spider, Arachnida. D. Robber-flies, Asilidae. E. Miscellaneous beetles, bees and wasps.

acteristic of the summer diet of the adult. The stomach contents of the 14 young birds mentioned above, which averaged 9 to 10 weeks in age, consisted of 60.5 per cent vegetable matter and 39.5 per cent animal matter. Animal matter found in the stomachs of two young prairie chickens is shown in figs. 14 and 15. The food of the 10 adults taken in the same period as the young birds consisted of 91.0 per cent vegetable matter and 9.0 per cent animal matter.

In the adult stomachs analyzed, wild seeds (exclusive of fruit) and grains made up over 40 per cent of the contents, with weed seeds greatly predominating. Buttonweed seeds constituted over 21 per cent of the total contents.

In the stomachs of the young birds, grain made up a greater volume than wild seeds (exclusive of fruit), most of which were buttonweed seeds. The grain con- material of both young and adults. Droppings examined in the field in July and early August contained quantities of dewberry or other Rubus seeds. Grange (19+1) in Wisconsin reports that the occurrence of the trailing swamp blackberry, Rubus hispidus Linnaeus, apparently determined the distribution of sharptailed grouse and prairic chickens during a portion of the day and at times for periods of days in the summer of $19+1$.

The consumption by prairie chickens of large numbers of short-horned grasshoppers, figs. $1 t$ and 15 , must be regarded as a definite asset to agriculture. Other harmful kinds of insects eaten by the Illinois prairie chickens include snout beetles, scarab beetles, leaf beetles, cutworms and leafhoppers. Certain beneficial forms, including ground beetles, lady beetles and grub parasites, were eaten to some extent.

There is no evidence from field studies 
that surface water for drinking is essential to either young or adult prairie chickens in Illinois. Probably dew meets part of the water requirements of these birds in summer, as Stoddard (1931) found in the case of bobwhites. In addition, the insect diet of the young birds and the fruit and green vegetation eaten by both young and old birds provide moisture when little free water is available. No evidence was found to indicate that prairie chickens made use of a small, intermittent stream in the Jasper County study area.

\section{MANAGEMENT}

Although definite limitations must be recognized in regard to management, it is evident that certain practical measures may be undertaken to insure the survival of prairie chickens in Illinois. That these birds can maintain themselves in good numbers in close contact with certain types of agriculture must be regarded as a highly encouraging sign. However, because of the possibility of future changes in agricultural practices, the present occurrence of prairie chickens over a fairly extensive district in southeastern Illinois must not be regarded with too much complacency.

Adequate legal protection and a wellbalanced system of public-owned refuges, these refuges involving the use of submarginal prairie lands and serving several kinds of wildlife, are essential to a sound prairie chicken management program for Illinois. Experimental stocking of suitable areas with trapped birds offers a possible means of increasing the range of prairie chickens in the state. Certain favorable land use practices are indispensable to the increase, or even the survival, of these birds. Needless to say, the successful prosecution of a long-time program for the management and conservation of prairie chickens and other wildlife depends to a considerable extent on the degree of public interest and cooperation in such an undertaking.

\section{Legal Protection}

Inasmuch as hunting of prairie chickens in Illinois has been prohibited under the State Game Code since the close of the 1932 season, and the present study was begun only 3 years after closure went into effect, it has been possible to make certain observations relative to the effect of legal protection on prairie chicken populations. In the northern part of the state, where prairie chickens have been decreasing steadily for many years, increased protection has probably been of material assistance in the case of some of the larger remnant colonies. Nevertheless, the amount of prairie chicken range in northern Illinois has continued to decrease since 1933 with the disappearance of numerous small colonies. Obviously, in the northern counties the benefits received under a closed season have not been able to compensate for the unfavorable environment.

In the main parts of the southeastern Illinois prairie chicken range, there has been no evidence of a general rise of population densities attributable to the closed season. However, prairie chickens have gradually extended their range in this region throughout the period covered by the present study. Although there is some evidence that this range extension began as early as 1930, when large acreages of farm land were idle, it is notable that it did not cease in the middle 1930's, when much of the idle land was put back into cultivation. It seems probable that even the relatively moderate hunting pressure exerted during the 1912-1932 period was sufficient to eliminate prairie chickens from the marginal portions of their range in southeastern Illinois, and that reoccupation of these areas is now possible because of the survival of larger numbers of birds annually.

Since prairie chicken population densities vary widely in different parts of the range, it is almost impossible with the data at hand to arrive at a satisfactory estimate of the number of these birds now present in Illinois. It is virtually certain, however, that the total population is only a small fraction of the number of resident upland game hunters in the state. An average of 12 chickens for each of the approximately 2,650 square miles comprising the main ranges in northern and southeastern Illinois would mean a total of about 32,000 birds. Even if the total number were twice as large, it would represent less than 1 bird to 5 licensed Illinois hunters. Moreover, unlicensed hunters, consisting of landowners and tenants and 
their children, all of whom can legally. hunt without licenses on the farm land on which they reside, are probably almost as numerous as licensed hunters. Although the number of licensed hunters living in the northern half of the state is preponderantly greater than the number living in the southern half, many northern hunters go annually to southern lllinois for quail hunting. In view of the heavy demand for upland game hunting in the localities now inhahited by prairie chickens, it is evident that the gun is potentially an important factor in the conservation of prairie chickens in Illinois.

Legalization of prairie chicken hunting on a statewide basis at the present time would inevitably hasten the extermination of the remaining birds in the northern part of the state. Resumption of chicken hunting in southeastern Illinois, except under such rigid restrictions as to furnish little sport for the great majority of hunters, would presumably soon bring a halt to the present extension of range and in time would be expected again to eliminate these birds from the poorer portions of their present range.

Unless the number of prairie chickens in Illinois can be increased materially, the status of this species of game bird will probably remain doubtful. In spite of the fact that fair-sized prairie chicken populations now occur in four or five southeastern Illinois counties, and smaller numhers in several other counties, until all available range in this region is reoccupied, and until adequate steps are taken to safeguard the colonies in other parts of the state, full legal protection seems advisable.

Loss to farmers through consumption of unharvested corn by prairie chickens in winter has sometimes been advanced as a reason for reopening the prairie chicken season. Although it is true that a number of complaints of damage were heard from farmers in some localities following the increase of chickens in 1938, only minur damage has been reported since that time. There seems little likelihood of increase of prairie chicken population densities to high levels in Illinois except for occasional short periods. During pericds of deep snow, which may temporarily increase consumption of grain by prairie chickens, trapping and transfer of birds to restock unoccupied regions offers a means of reducing damage in local areas.

\section{Refuges}

In northern lllinois, adequate refuge areas are the first necessity if the native prairie chickens of that region are to be preserved for the future. In Lee County, northern Illinois prairie chickens are making their last stand on approximately 50 square miles of sand prairie along the Green River. Much of this land consists of low dunes and is submarginal for agriculture. Bottomland areas, which are interspersed among the sand lands, are relatively fertile and are farmed or pastured intensively. Some of the pastured areas contain ponds or marshes and are leased for waterfowl shooting.

A 1,400-acre area has recently been purchased in Lee County as part of the Federal Aid in IVildlife Restoration Act program to serve as an upland game, furbearer and waterfowl refuge. 'This area, administered by the State Department of Conservation, is a forward step toward safeguarding the remnant prairie chicken population, although it is too small for an ideal chicken refuge. An area of 25 square miles probably represents the minimum that would serve as an adequate sanctuary for prairie chickens in this region.

The relatively high cost of bottomland soil is recognized as a serious obstacle to the acquisition of an adequate refuge area in the northern Illinois prairie chicken range. Careful blocking to include chiefly light sandy land would reduce the cost of acquisition. Nevertheless, inclusion of marsh areas and ponds would greatly increase the usefulness of such a refuge. These bottomlands furnish important habitats for prairie chickens, furbearers and other species of wildlife. 'They are among the few places where waterfowl now nest within the state. A well-managed refuge area of adequate size, consisting of perhaps 80 per cent upland sandy areas and 20 per cent marsh would be an important contribution to the conservation of wildlife, including a number of species that are now rare as residents or nesting forms within the state, for example, mallards, pintails, blue-winged teals, king rails, upland plovers and badgers, in addition to prairie chickens. It should incidentally 
serve also as a sanctuary for prairie flowers and herbaceous plants, many of which are now rare in the state.

This area would, perhaps, eventually develop forest cover if withdrawn entirely from farming and grazing. Its usefulness as a wildlife sanctuary would depend on keeping a large part of it in open grassland. To accomplish this might require a special program similar to one outlined by Grange (1942) in Wisconsin, including perhaps controlled grazing, or farming on some of the better portions, and also controlled burning practices.

Since prairie chickens on the area would undoubtedly feed in winter on nearby farmed areas, an extensive system of food patches probably would not be strictly necessary, but, in case farming is adopted in the more fertile areas to maintain open land, some of the grain crops, especially corn, should be left standing to furnish winter food for wildlife.

From the standpoint of prairie chicken management, the chief native vegetation required would be species for budding; cottonwood, a favorite species in southern Illinois, would seem suitable for planting in small numbers in the northern Illinois range. A few aspen, wild cherry, panicle dogwood and hazel plantings might also be made if these species are absent. Development of widely scattered bramble growth, preferably dewberries, would provide summer food, as well as improve nesting areas.

\section{Leasing Land for Refuges}

Although solid blocks or closely grouped tracts of land are probably the most satisfactory from the standpoint of administration of public-owned refuge areas, good prairie chicken management practices do not require that refuge areas he contiguous, provided proper distribution of smaller refuge areas can be obtained. For example, certain sand prairie townships in northern Illinois which now have a few prairie chickens might be converted into good chicken range by leasing, and converting to refuges for a term of years, 25 per cent of the total land in the form of 20 -acre, +0 -acre or larger tracts of the poorer farm soil throughout each township. Except when control of woody vegetation is necessary on these areas, no graz- ing should be permitted and adequate protection from fire would be necessary.

\section{Farming Practices}

That prairie chickens are still making a strong stand in the redtop producing area of Illinois demonstrates that these birds are not necessarily eliminated by agriculture and suggests that the farming practices followed in this area may serve as a guide in making management recommendations.

The present general characteristics of the southeastern Illinois prairie chicken range may be summarized by stating that this range consists principally of prairie soils of relatively low fertility in mixed farming areas where annually 6 to 8 per cent of the total farm land is idle and about 15 to more than 25 per cent is in redtop. As suggested previously, these areas present favorable conditions for prairie chickens because redtop as well as idle fields produce cover and nesting places quite early in the spring, and the redtop is harvested relatively late, allowing most of the young birds to get on the wing hefore the cover is removed, fig. 16. 'The densest populations of prairie chickens occur in localities of relatively high redtop acreages, and, as a rule, the greater the amount of redtop harvested for seed, rather than hay, the hetter the range.

Since about half of the acreage of idle land in southeastern Illinois has developed sufficient grass to furnish nesting cover, it may be said that grass type cover occupies from approximately 20 to more than 30 per cent of the total farm land in the various localities occupied hy prairie chickens. Presumably similar acreages of grassland and similar farming practices would create prairie chicken range anywhere they might be applied on the Illinois prairie. Undoubtedly the cover requirements may under certain conditions be met by considerably smaller acreages of grassland than those given above, as indicated by Bennitt's (1939) studies in Missouri, hut because of the many factors involved no conclusions can be drawn here as to minimum cover requirements.

Since the redtop producing area will probably remain the chief potential range of prairie chickens in the state, and must be considered as very important in any 
management program involving these birds, the future of the redtop industry is of special interest to wildlife conservationists.

As Burlison, Stewart, Ross \& Whalin (193t) point out, the concentration of redtop seed production in southeastern
Illinois, reduction of the average acreage of redtop grown on individual farms will probably result in lower population densities than occur at present. Increased grazing will also tend to reduce the amount of habitable range. Nevertheless, the changes forecist by the study mentioned

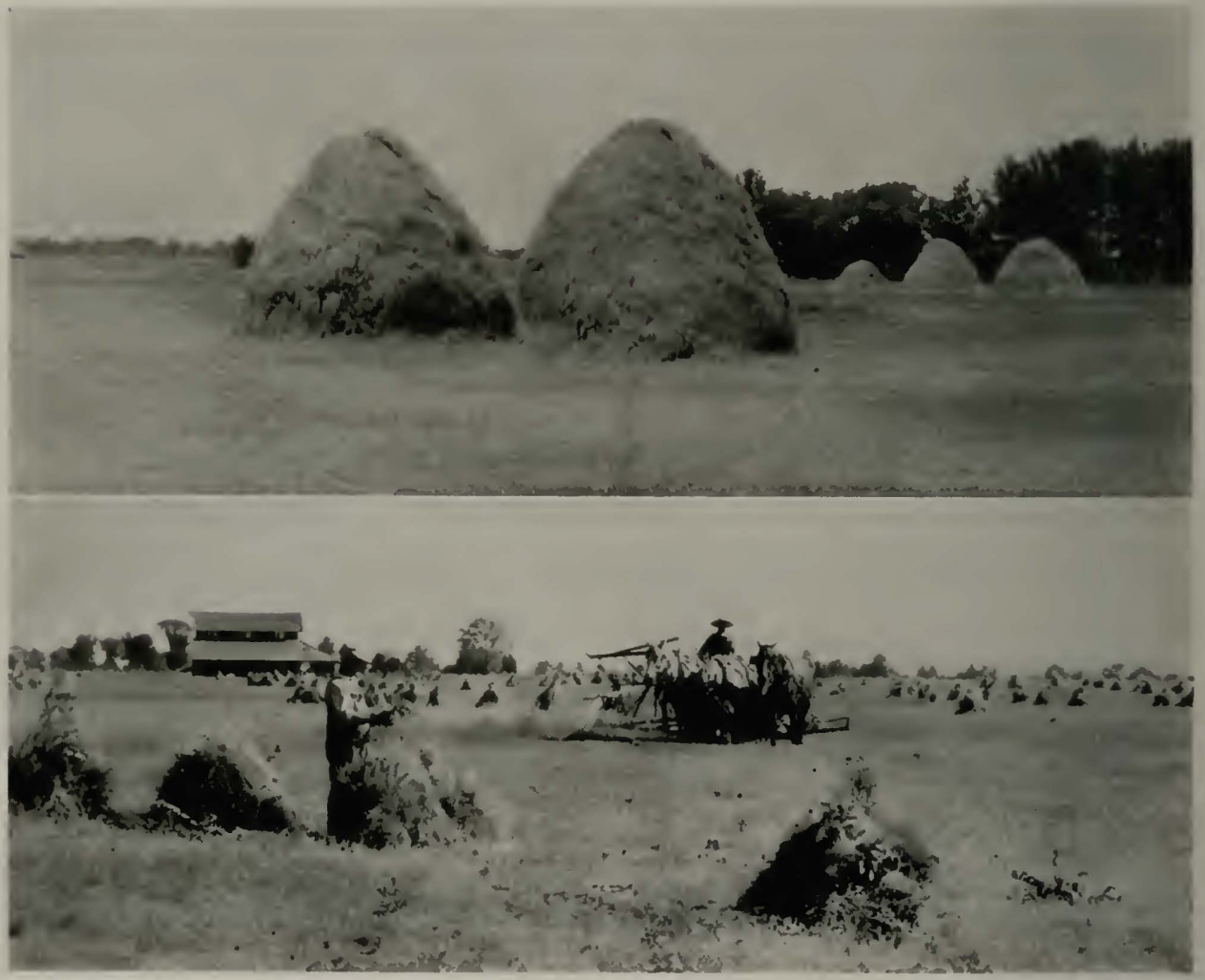

Fig. 16.- Harvesting redtop. Redtop grown for seed may be cut with a mowing machine and stacked (above) or with a binder and shocked (below). The latter method of harvest provides better late summer and fall cover for prairie chickens because of the taller stubble. (Photograph by courtesy of the Department of Agronomy, University of Illinois College of Agriculture.)

Illinois is due to a combination of factors that favor the continuation there of the present type of farming. However, these authors warn that, hecause of overproduction of seed and declining soil fertility under present farming practices, a reduction of the average acreage of redtop on farms now producing this crop is in prospect. Increased grazing of redtop fields by livestock is mentioned as a probable part of such readjustment.

As far as can now be foreseen, although conditions will continue to favor the survival of prairie chickens in southeastern above will serve to put the redtop business on a stable, though reduced, basis and they probably will not in themselves eliminate prairie chickens from any large part of the prairie soils these birds now occupy.

Even though the general trend of southeastern Illinois agricultural practices is slightly unfavorable to prairie chickens, individual landowners can assist in maintaining the populations at or near their present levels if they will practice moderate grazing of pastures, avoid burning of idle fields in the spring months and refrain, whenever possible, from disturb- 
ing strips of idle grassland in which prairie chickens are known to be nesting.

In the dark soil counties of Illinois, prior to World War II, a trend was evident toward greater use of grass crops for hay, pasture and soil conservation. This trend, now interrupted by the necessity for greater grain production, may be resumed after the war.

Although it is unlikely that future agricultural developments will be of a nature to encourage the return of prairie chickens to large areas of intensively farmed dark soil prairie, it is possible that local conditions will permit the re-establishment of small populations of these birds in certain places. In some cases, small colonies of prairie chickens have persisted for many years in the dark prairie around grazed marshes, large pastures or other accidentally preserved areas of favorable range. It is our conclusion that only slight changes, consistent with sound farm management, would be necessary to create favorable environment for prairie chickens on many dark soil prairie farms. Controlled grazing, use of sweet clover as pasture during the spring and early summer, use of June clover, lespedeza and alsike as hay or seed crops, growing of mixed clover and timothy for hay, and reduction of the acreage of land annually plowed for spring crops, are indicated by field observations to be favorable to prairie chickens in the dark soil counties.

Observations made in southeastern Illinois indicate that the practice of supplying strips of undisturbed grassland bordering ditch banks and cultivated fields is a possible method of supplementing the present nesting cover in dark soil counties, but this method must be tried experimentally before conclusions can be reached as to its effectiveness.

\section{Predator Control}

The presence of normal predator populations along with relatively high populations of prairie chickens on southeastern Illinois farm lands gives a good indication that widespread predator control would be unnecessary or unprofitable in prairie chicken management. On refuges or management areas, the conditions actually existing on the ground should be the guide to predator control activities.
Large numbers of crows on refuges might cause undue loss of nests or young of prairie chickens. Cooper's hawks, if at all numerous, would be undesirable during the nesting season. On the other hand, the great majority of species of hawks and owls, as well as predatory mammals, can well be left undisturbed hecause of their activity in controlling ground squirrels and other rodents. Feral cats and dogs have no place on game preserves. Cats especially may be serious enemies of young prairie chickens (Lehmann 19+1).

Normal harvesting of an annual crop of the common furbearing animals might be expected to exercise sufficient control to keep these forms from hecoming overabundant and unduly destructive. As previously pointed out, evidence is lacking that foxes in moderate numbers exert any appreciable effect on prairie chicken populations. However, if it becomes evident that any particular form of predator has increased abnormally and is destructive, special efforts to reduce the population of that form to normal may be necessary.

No general program of predator control involving the use of pole traps or other nonselective devices that may take a heavy toll of harmless or beneficial species (Wight 1931) can be recommended for refuge areas. Control should be restricted to individual predators or species for which there is evidence of activities actually harmful to game birds.

\section{Trapping and Restocking}

The fact that agricultural practices change periodically on the Illinois prairic in response to market demands, and to developments in soil, water conservation and other factors, makes it possible that limited areas from which prairie chickens have disappeared may now or at a later time be successfully restocked by releasing trapped birds. Other areas of potential restored or increased range include fairsized tracts withdrawn from agriculture, such as those surrounding munition plants in prairie districts, and the sites of existing prairie chicken colonies where landowners are willing to practice special management measures for the benefit of these birds.

Successful transplantation of prairie chickens in local areas has been reported 


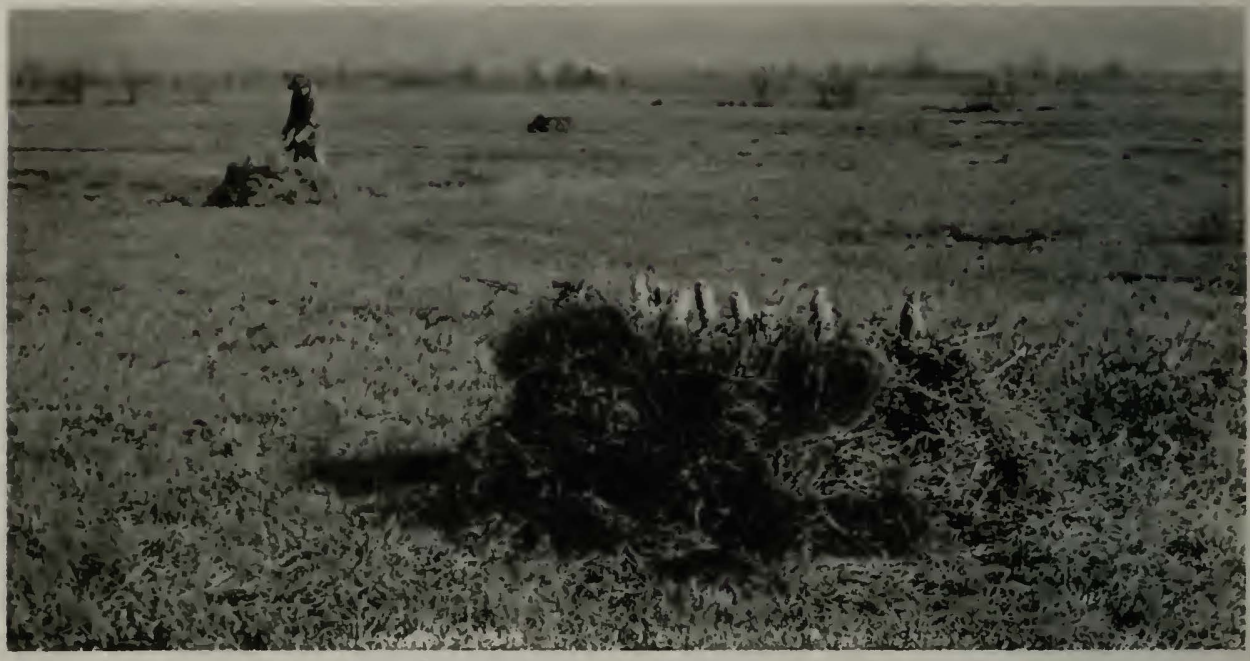

Fig. 17. Tip-fop traps used in trapping prairie chickens in southeastern Illinois, Feh. 9, 19+0. The traps are covered with vegetation to make them less conspicuous.

in certain midwestern states, notably Michigan. Selection of suitable sites and the release of adequate numbers of birds are probably the chief factors in the success of stocking attempts. Trapping operations carried on by the Illinois Natural History Survey show that, with favorable weather conditions, southeastern Illinois prairie chickens can be trapped in winter at reasonable cost. A survey of possible sites for releases and the stocking of some of the most favorable areas on an experi- mental basis can well be part of a sound prairie chicken management program in Illinois.

Tip-top traps have been used with some success for trapping prairie chickens in southeastern lllinois, figs. 17 and 18 . Since scarcity of snow makes trapping unproductive, sufficient equipment would be necessary to trap intensively during the relatively short periods of deep snow that occur in that region. Experiments with varicus types of traps (Hamerstrom 19+2)

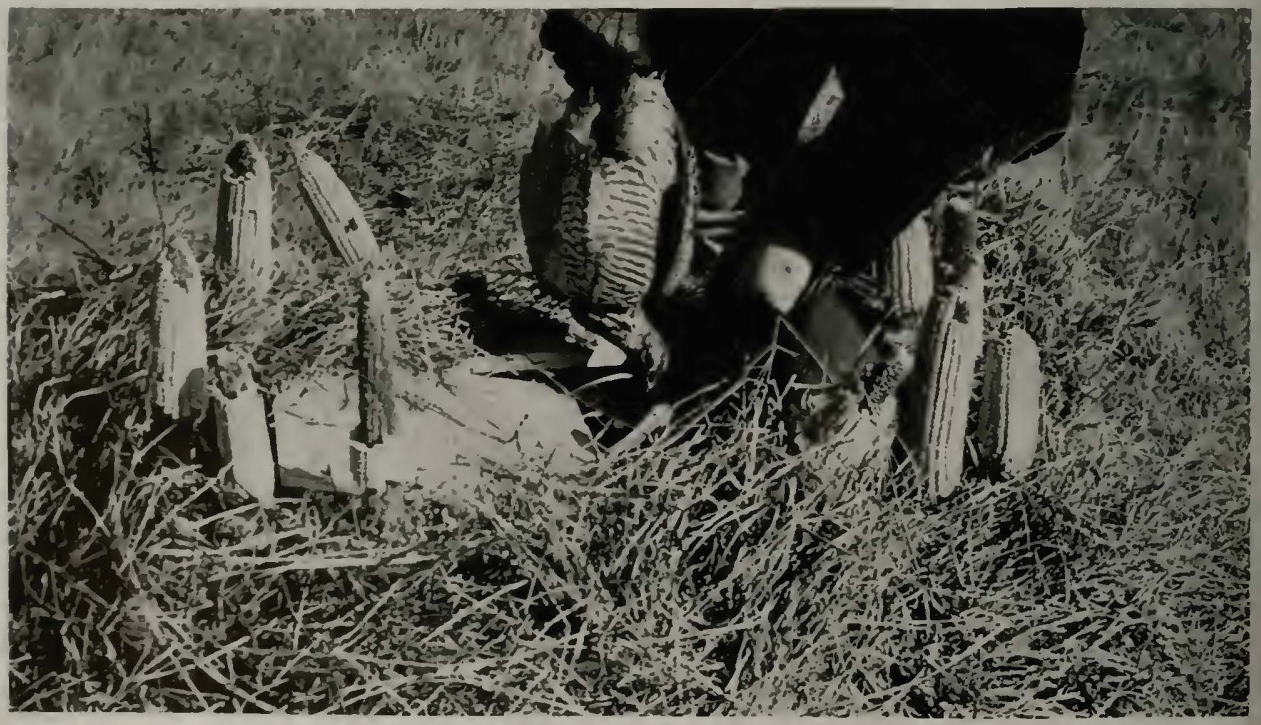

Fig. 18.-Removing a prairie chicken from a tip-top trap in southeastern Illinois. Corn and soybeans have proved to be the most attractive baits in this area. 
would undoubtedly result in improved methods of trapping in Illinois.

\section{Public Interest}

That prairie chickens were formerly numerous throughout the Illinois prairie is well known. It is less generally realized that in a few counties these birds are still fairly abundant and may be seen and heard each spring during their courtship performance, even from paved highways running through settled farming communities.

In view of the fact that the prairie chicken was an outstanding species of Illinois wildlife in early times, and one that played an important part in numerous chapters of our pioneer history, it is unfortunate that serious consideration was not given to it when the official state bird was chosen. It is a typical resident of the grasslands of the Middle IVest, while the colorful and sprightly cardinal, our present state bird, is a representative of the fauna of the southern United States. Unlike the cardinal, which has been chosen as the official bird of nearly a dozen states, the prairie chicken has been adopted by no other state.

Because of the present restricted distribution and comparative rareness of prairie chickens in Illinois, relatively few residents of the state have had an opportunity to observe these truly magnificent birds in the field. Fortunately, in recent years some excellent moving picture shots of Illinois prairie chickens have been made. These pictures, now available to the public, have already proved of material value in arousing interest in the welfare of prairie chickens in this state.

Public interest and cooperation are essential to the success of any program designed to conserve and increase the numbers of prairie chickens in Illinois.

\section{SUMMARY}

1. Prairie chickens were originally distributed over the grasslands of Illinois. During the early stages of agricultural development, they extended their range to the cleared woodland soils and increased in numbers, probably reaching their highest populations in the 1860 's. Thereafter they declined sharply, chiefly as a result of the rapid expansion of agriculture, which about 1880 involved a larger acreage than at present.

2. 'The present range of prairie chickens in Illinois is approximately 9 per cent of the original range and includes about 50 square miles in Lee County, northern Illinois, 2,600 square miles in southeastern Illinois and a number of small isolated colonies, principally in the northern and south central counties. Much of the information contained in this report is the result of research carried on since 1935 in a study area, 2 by 2 miles square, in Jasper County, southeastern Illinois.

3. In northern Illinois, prairie chickens are in danger of extermination, but in southeastern Illinois these birds are at present maintaining themselves in fair numbers.

t. The chief areas occupied by lllinois prairie chickens are on prairie soils of low fertility where special farming practices and idle land are favorable to the preservation of these birds.

5. The southeastern Illinois prairie chicken range, the largest and most important in the state, is in a district where redtop grass is grown extensively. This grass provides favorable habitats throughout the year, but its principal benefit to prairie chickens is that it furnishes undisturbed grass cover during the nesting season and while the birds are very young.

6. In southeastern Illinois, the first evidence of sexual display in the male prairie chickens occurs on booming grounds in late January or early February. This display reaches a climax in late April and ends about mid June.

7. There is evidence of a time differential in the development of the sexual cycle among both male and female prairie chickens. This differential is evident in the males from a variation in the stage of development in pigmentation of throat and eye regions, as well as in sexual activity, among males on the same booming ground.

8. The differential sexual development of females is indicated by a time spread in the dates on which individuals lay their first eggs, and also by a considerable spread in dates of hatching, not all of which can be attributed to renestings. Field records show that hatching begins in early May, reaches a peak in the first half 
of June and tapers off during the first half of July.

9. Only 1 of approximately 20 booming grounds under observation each spring was used continumusly for as long as 7 years.

10. In southeastern lllinois, prairie chickens may hegin to Hock as early as mid August. Winter Hocks commonly range from 12 to 75 birds.

11. Prairie chickens tend to congregate in certain local areas to spend the winter. Dispersal from the wintering grounds takes place in March.

12. Prairie chickens show a preference for grassy cover throughout the year.

13. The areas used for nesting in southeistern Illinois are (1) redtop fields, (2) idle fields, chiefly those that are entering the grassland stage of succession, (3) small tracts of waste grassland.

14. In the years covered by this report, and in the region most carefully studied, low ditch banks, an abandoned railroad bed and other small waste areas of bluegrass were found to be the most intensively used nesting sites.

15. The average size of 12 full clutches of prairie chicken eggs was 12.3 .

16. Although concentrations of many nests in limited areas of nesting cover are reported as formerly occurring in Illinois, the highest density found during the present study was 1 nest per acre.

17. The chief causes of nesting losses in southeastern Illinois are (1) predators, (2) nest desertion by the female, (3) farming operations, $(t)$ failure of eggs to hatch.

18. Nineteen, or 49 per cent, of 39 nests under observation were successful.

19. Ninety-three per cent of 148 eggs that underwent normal incubation hatched successfully.

20. Many of the nest losses in southeastern Illinois occur early in the nesting season. Such losses seem to be largely compensated for by renesting.

21. Although attempts to renest are occasionally begun in this region as late as mid July, there is no evidence that nests begun after the middle of June produce a significant number of young.

22. Fall censuses of the Jasper County study area, beginning in 1935 and ending in $19+1$, showed a variation in population densities of from 1 bird per 10 acres to
1 bird per 18 acres. The average was 1 bird per 14.3 acres.

23. Evidence as to whether prairie chickens are cyclic in southeastern lllinois is inconclusive.

24. 'The causes of prairic chicken mortality indicated by the present study include predators, pathological factors, accidents, illegal hunting and certain hazards that are peculiar to infant and juvenile periods.

25. Brood studies in the summers of 1935 and 1936 indicated an average loss of approximately +6 per cent of the young birds during the first 5 weeks after hatching.

26. Predator studies in southeastern Illinois failed to reveal serious pressure on prairie chickens by any particular predatory species.

27. There is some evidence of losses of young prairie chickens from pathological causes.

28. Illegal hunting appears to be a serious factor where it involves small isolated colonies.

29. Analysis of the stomach contents of 14 young birds, of an average age of 9 to 10 weeks, collected in June, July and August, 1936 and 1937, showed the following percentages by volume of foods eaten: animal matter, chiefly insects, 39.5 per cent; fruit 22.6 per cent; grain 18.9 per cent; wild seeds (exclusive of fruit) 12.0 per cent ; browse $6 . t$ per cent ; vegetable debris 0.6 per cent.

30 . The volumetric percentages of various foods found in the stomachs of 10 adult birds, collected during June, July and August, 1936 and 1937, were as follows: wild seeds (exclusive of fruit) 35.6 per cent; fruit 31.3 per cent; browse 17.7 per cent; insects 9.0 per cent; grain 4.7 per cent; vegetable debris 1.2 per cent ; acorns 0.5 per cent.

31. Grains, especially waste corn and soybeans, and weed seeds are an important part of the winter diet of prairie chickens in southeastern Illinois. These birds consume buds of trees and shrubs to some extent from late fall until April.

32. Prairie chicken management in Illinois involves (1) legal protection, (2) the establishment of refuges in certain areas, (3) farming practices that provide favorable habitats, (4) trapping and restocking of birds in favorable places, (5) 
a public interested in the prairie chicken and its welfare.

33. The recent extension of prairie chicken range in southeastern lllinois seems to be due largely to the closed season in effect since the end of the 1932 hunting season.

34. The hunting season on prairie chickens in Illinois should not be reopened until (1) there has been a considerable increase in the total number of prairie chickens in the state and (2) strategically located remnant populations have been safeguarded through the establishment of permanent refuge areas.

35. Refuges are urgently needed in northern Illinois. Such refuges should involve submarginal prairie lands and should benefit several wildlife species in addition to prairie chickens.

36. Refuge management should insure keeping a large part of the refuge areas in grassland.

37. In southeastern Illinois, prairie chickens are well adapted to living in prairie farming districts where from 20 to 30 per cent of the total agricultural land is grass type cover that is not disturbed until July 1 or later. Presumably, similar grass acreages and farming prac- tices would create fair to good prairie chicken range anywhere they might be applied on the lllinois prairic.

38. Other farming practices that favor prairie chickens are moderate grazing, prevention of burning of grassland areas and use of late-harvested hay crops such as June clover, lespedeza, or mixed grasses and legumes.

39. The present outlook for redtop culture in southeastern lllinois indicates that the size of the prairic chicken range will not be reduced materially but that population densities in certain localities may be somewhat lower.

40. In the best interests of prairie chickens and other desirable wildlife species, nonselective predator control programs should be avoided on refuge areas. If control is necessary, it should be confined to individuals or species that are known to be doing harm.

41. Trapping prairie chickens where the birds are most abundant and releasing them experimentally in favorable areas elsewhere in the state offers a possible means of increasing the present range.

42. Public interest and cooperation are essential to il successful prairie chicken management program.

\section{I T E R A T UR E C I T E I)}

\section{American Field}

1881. Answers to correspondents. 16(9): 135. Aug. 27.

\section{Bennitt, Rudolf}

1939. Some agricultural characteristics of the Missouri prairie chicken range. N. Am. Wildlife Conf. Trans. 4:491500 .

Bennitt, Rudolf, and Werner O. Nagel

1937. A survey of the resident game and furbearers of Missouri, Mo. Univ. Studies 12(2): 1-215.

Bent, Arthur Cleveland

1932. Life histories of North American gallinaceous birds. U. S. Natl. Mus. Bul. 162:1-490.

Burlison, W. L., C. L. Stewart, R. C. Ross and O. L. Whalin

1934. Production and marketing of redtop. III. Ag. Exp. Sta. Bul. 404:231-99. $2+$ figs.

Case, H. C. M., and K. H. Myers

1934. Types of farming in Illinois: an analysis of differences by areas. 111. Ag. Exp. Sta. Bul. 403:97-226. to figs.
Davison, Verne E.

1940. An 8-year census of lesser prairie chickens. Jour. Wildlife Mgt. $f(1)$ : 55-62.

Errington, Paul L.

1937. Food habits of the red fox in lowa. An. Wildlife 26(1):5-6, 13.

Errington, Paul L., and W. J. Breckenridge 1936. Food habits of marsh hawks in the glaciated prairie region of north central Enited States. Ain. Midland Nat. 17(5):831-+8.

Errington, Paul L., and F. N. Hamerstrom, Jr. 1937. The evaluation of nesting losses and juvenile mortality of the ring-necked pheasant. Jour. Wildlife Mgt. 1(12) : 3-20.

Errington, Paul L., Frances Hamerstrom and F. N. Hamerstrom, Jr.

19+0. The great horned owl and its prey in north central United States. Lowa State Col. Res. Bul. 277:759-850.

Forbes, Stephen A.

1912. The native animal resources of the state. Ill. Acad. Sci. Trans. 5:37-48. 
Grange, Wallace 13.

1940. A comparison of the displays and vocal performances of the greater prairie chicken, lesser prairie chicken, sharp-tailed grouse and sooty grouse. Passenger Pigeon 2(12) :12733.

19+1. Quarterly progress report, grouse research, Federal Aid in Wildlife Restoration Act. Wis. Wildlife Res., Wis. Cons. Dept. 1(3):12-61. 2 figs.

19+2. Quarterly progress report, grouse research, Feleral Aid in Wildlife Restoration Act. Wis. Wildlife Res., Wis. Cons, Dept. 2(2):10-67. 8 figs.

Gross, Alfred O.

1930. Progress report of the Wisconsin prairie chicken investigation. Wis. Cons. Comm., Madison. 112 pp.

Hamerstrom, Frederick N., Jr.

1939. A study of Wisconsin prairie chicken and sharp-tailed grouse. Wilson Bul. 51 (2) : 105-20.

19+1. A study of Wisconsin prairie grouse (breeding habits, winter foods, endoparasites, and movements). Unpublished thesis (blueprint copy). Wis. Univ. Dept. Wildlife Mgt. $1+8 \mathrm{pp}$.

19+2. Progress report No. 5, 19+0-19+1, Prairie Grouse Cooperative. Wis. Univ. Dept. Wildlife Mgt. 36 pp., illus. (Mimeographed.)

Johnson, Charles Eugene

1934. Recollections of the prairie chicken and the sharp-tailed grouse in northwestern Minnesota. Wilson Bul. 46 (1) : 3-17.

Judd, Sylvester Dwight

1905. The grouse and wild turkeys of the United States and their economic value. U. S. Bur. Biol. Surv, Bul. 24.

Lehmann, Valgene W.

1939. Heath hen of the south. Am. Wildlife $28(5): 221-7$.

19+1. Atwater's prairie chicken: its life history and management. U. S. Fish and Wildlife Serv. N. Am. Fauna 57. 65 pp., illus.

Leish, W. Henry

1939. The food of young marsh hawks. Wilson Bul. $51(4): 2+1-2$.

1940. Preliminary studies on parasites of upland game birds and fur-bearing mammals in Jllinois. Ill. Nat. Hist. Surv. Bul. 21 (5) :185-94. Frontis., 2 figs.

Leopold, Aldo

1931. Report on a game survey of the north central states. Sporting Arms and Ammunition Mfg. Inst., Madison, Wis. 299 pp., illus.
1933. Game management. Charles Scribner's Sons, New York. xxi ++81 pp., illus., index.

1936. Franklin J. W. Schmidt. Wilson Bul. $48(3): 181-6$.

McAtee, W. L.

1935. Food habits of common hawks. U. S. Dept. Ag. Circ. 370:1-36, 17 figs.

Main, John S.

1937. The dance of the prairie chicken. Wilson Bul. 49(1):37-+2.

Merritt, H. Clay

1904. The shadow of a gun. F. T. Peterson Company, Chicago. +50 pp., frontis., illus.

Middleton, A. D.

1935. Factors controlling the population of the partridge (Perdix perdix) in Great Britain. London Zool. Soc. Proc., pp. 795-815.

Randall, Pierce E.

1940. The life equation of the ringneck pheasant in Pennsylvania. N. Am. Wildlife Conf. Trans. 5:300-20. 9 figs., bibliog.

Romanoff, Alexis L., Gardiner Bump and Earl Holm

1938. Artificial incubation of some upland game birds' eggs. N. Y. State Cons. Dept. Bul. 2:1-t+.

Schmidt, F. J. W.

1936. Winter food of the sharp-tailed grouse and pinnated grouse in Wisconsin. Wilson Bul. 48(3) : 186-203. Illus., bibliog.

Stoddard, Herbert L.

1931. The bobwhite quail; its habits, preservation and increase. Charles Scribner's Sons, New York. xxix +559 pp., 69 pls. (part color, including frontis.), 32 figs., appendix, index.

Uhler, F. M., C. Cottam and T. E. Clarke.

1939. Food of snakes of the George Washington National Forest, Va. N. Am. Wildlife Conf. Trans, 4:605-22.

Vestal, Arthur G.

1931. A preliminary vegetation map of Illinois. Ill. Acad. Sci. Trans. 23 (3) :204-17.

Wight, H. M.

1931. The effect of pole traps on harmless and beneficial species. Wilson Bul. $43(t): 282-92$.

Yeatter, Ralph E.

1934. The Hungarian partridge in the Great Lakes region. Mich. Univ. School Forestry and Cons. Bul. 5: 1-92. Illus. 